\title{
Phytoplankton production in the North Water Polynya: size-fractions and carbon fluxes, April to July 1998
}

\author{
Zhi-Ping Mei ${ }^{1,6, *}$, Louis Legendre ${ }^{1,2}$, Yves Gratton $^{3}$, Jean-Éric Tremblay ${ }^{4}$, \\ Bernard LeBlanc $^{1}$, Bert Klein ${ }^{1}$, Michel Gosselin ${ }^{5}$ \\ ${ }^{1}$ GIROQ, Department of Biology, Laval University, Sainte-Foy, Québec G1K 7P4, Canada \\ ${ }^{2}$ Laboratoire d'Océanographie de Villefranche (LOV), BP 28, 06234 Villefranche-sur-Mer Cedex, France \\ ${ }^{3}$ INRS-Eau, 2800 rue Einstein, Sainte-Foy, Québec G1K 4C7, Canada \\ ${ }^{4}$ McGill University, Department of Biology, 1205 Dr. Penfield, Montreal, Québec H3A 1B1, Canada \\ ${ }^{5}$ Institut des sciences de la mer (ISMER), Université du Québec à Rimouski, 310 Allée des Ursulines, Rimouski, \\ Québec G5L 3A1, Canada
}

${ }^{6}$ Present address: Institut des sciences de la mer (ISMER), Université du Québec à Rimouski, 310 Allée des Ursulines, Rimouski, Québec G5L 3A1, Canada

\begin{abstract}
In order to understand the mechanisms responsible for the high productivity and biogeochemical cycling of carbon in the North Water Polynya (NOW), we determined physical properties and nutrient concentrations of the upper water column, and phytoplankton production, during spring/summer (April to July) 1998. Phytoplankton production of total organic carbon $\left(P_{\mathrm{TOC}}\right)$ was partitioned into production of dissolved and particulate organic carbon $\left(P_{\mathrm{DOC}}\right.$ and $P_{\mathrm{POC}}$, respectively), the latter being further partitioned into production of large and small phytoplankton $\left(P_{\mathrm{L}}\right.$ and $P_{\mathrm{S}}$ respectively) using $5 \mu \mathrm{m}$ as threshold. The highest $P_{\text {TOC }}$ was $6 \mathrm{~g} \mathrm{C} \mathrm{m}^{-2} \mathrm{~d}^{-1}$ at peak bloom. The fraction of $P_{\mathrm{DOC}}$ in $P_{\mathrm{TOC}}$ was lower in periods of high $P_{\mathrm{TOC}}$ than those of low $P_{\mathrm{TOC}}$. Averaged over the whole polynya for the sampling period, $P_{\mathrm{DOC}}$ and $P_{\mathrm{POC}}$ accounted for 34 and $66 \%$ of the fixed carbon, respectively, and 81 and $19 \%$ of $P_{\mathrm{POC}}$ were in the $P_{\mathrm{L}}$ and $P_{\mathrm{S}}$ fractions, respectively. Variations in the integrated assimilation numbers of large and small phytoplankton were mostly explained by nutrients and irradiance. Even though $P_{\mathrm{POC}}$ was dominated by large phytoplankton, the sinking rates of the phytoplankton cells were relatively low $\left(0\right.$ to $\left.0.7 \mathrm{~m} \mathrm{~d}^{-1}\right)$, hence low export of $P_{\mathrm{POC}}$ to depth $(17 \%)$, and relatively high potential transfer to large pelagic organisms through the herbivorous food web. This explains why the NOW is a major feeding and spawning area for fish, mammals and birds.
\end{abstract}

KEY WORDS: Primary production · Phytoplankton biomass · Dissolved organic carbon · Particulate organic carbon $\cdot P_{\text {opt }}^{\mathrm{B}} \cdot$ Export $\cdot$ Biogeochemical cycling $\cdot$ North Water $(N O W)$ Polynya

\section{INTRODUCTION}

Polar oceans are particularly sensitive to global warming because increased temperature reduces ice concentration and increases water column stability. These 2 factors affect biological processes in marine ecosystems. Phytoplankton production plays a central role in the biogeochemical cycling of carbon in the upper ocean. For example, marine phytoplankton are fixing

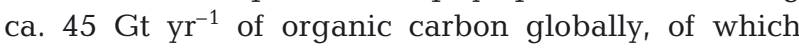
about $1 / 3$ is exported downwards (Falkowski et al. 1998). With global warming, the surface layer of the World Ocean is predicted to become more stratified by freshwater input from the melting of ice caps at high latitude, and increased temperature at lower latitudes. Over the long term, this would lead to reduced nutrient 
supply from the depth to the surface, and hence, reduced production and export of organic carbon from the surface layer, thereby lowering the biologically driven flux of atmospheric $\mathrm{CO}_{2}$ into the ocean (Falkowski et al. 1998).

In order to better estimate phytoplankton production of the World Ocean, more data on the characteristics of phytoplankton photosynthesis are needed (Sathyendranath et al. 1995). Chlorophyll-specific phytoplankton production, or assimilation number $\left(P^{\mathrm{B}}, \mathrm{g} \mathrm{C} \mathrm{g} \mathrm{chl}^{-1}\right.$ $\mathrm{h}^{-1}$ ) of marine phytoplankton, is required to estimate phytoplankton production from remotely sensed chlorophyll a concentrations. The up-scaling of in vitro phytoplankton production from single stations to large oceanic regions, and from instantaneous estimates to longer temporal scales, requires understanding the interactions between the characteristics of phytoplankton production and the physical and chemical properties of marine waters. This is because intermittent variations in the physical forcing frequently drive short-term and small-scale variations in phytoplankton production (Platt et al. 1989). In addition, the physical dynamics of the water column are believed to determine the partitioning of phytoplankton production and biomass among different size fractions (Tremblay et al. 1997b).

The role of the Arctic Ocean as a carbon source or sink is not certain as yet, due to insufficient knowledge of its primary production regime (Walsh 1989). Even though data on primary production in the Arctic Basin are accumulating (Kristiansen et al. 1994, Cota et al. 1996, Pomeroy 1997), especially since satellite images for chlorophyll have become available, data on the partitioning of production into different size fractions of biogeochemical significance, i.e. dissolved organic carbon (DOC) and particulate organic carbon (POC) of different sizes, started to become available only recently in the Arctic Basin (Gosselin et al. 1997) and Arctic polynyas (Pesant et al. 1996, Klein et al. 2002). Phytoplankton of different sizes differ in their physiological responses to physical and chemical conditions of the water column, following the laws of allometry (Chisholm 1992, Finkel \& Irwin 2000). The flux of photosynthetically produced carbon by phytoplankton within the pelagic food web depends on the partitioning among DOC and POC of small and large phytoplankton (Legendre \& Le Fèvre 1989, Tremblay \& Legendre 1994, Legendre \& Rassoulzadegan 1996). Field data and modeling exercises show that the production of large phytoplankton $\left(P_{\mathrm{L}}\right)$ often corresponds to new production (i.e. production supported by nitrate uptake), and that of small phytoplankton $\left(P_{\mathrm{S}}\right)$ to regenerated production (i.e. production supported by regenerated nitrogen, such as ammonium) (Tremblay et al. 1997a), although small phytoplankton can contribute substantially to nitrate uptake (Dauchez et al. 1996 for the Scotian Shelf and NW Atlantic, Bury et al. 2001 for the North Atlantic, Tremblay et al. 2000 for the Gulf of St. Lawrence). Therefore, not only the amount of inorganic carbon fixed by autotrophic photosynthesis, but its subsequent allocation to different size fractions are becoming focuses of production research.

The North Water Polynya (NOW, north of Baffin Bay between Ellesmere Island and Greenland) is one of the most productive areas in the Arctic (Stirling 1980, Klein et al. 2002, Tremblay et al. 2002b). The timing of photosynthetic fixation of organic carbon relative to such physical processes as the opening and closing of the ice cover and water column mixing determines the role of Arctic polynyas as carbon sinks or sources. In the present study, phytoplankton production in the NOW was partitioned into production of dissolved $\left(P_{\mathrm{DOC}}\right)$ and particulate organic carbon $\left(P_{\mathrm{POC}}\right)$, and the latter into large $\left(P_{\mathrm{L}}\right)$ and small sized fractions $\left(P_{\mathrm{S}}\right)$, using a threshold of $5 \mu \mathrm{m}$. The $5 \mu \mathrm{m}$ threshold was selected based on the fact that mesozooplankton graze phytoplankton $>5 \mu \mathrm{m}$ most efficiently (Fortier et al. 1994). The purpose was to investigate the effects of physical and chemical characteristics, especially light and nutrients, on the photosynthetic characteristics of phytoplankton in different size classes, and to quantify the photosynthetic fixation of organic carbon into different size fractions. Our first hypothesis was that the photosynthetic characteristics of phytoplankton of different sizes varied differently with physical and chemical properties such as light, nutrients and water temperature, which would determine the production of carbon in different size fractions.

The NOW is known as a major spawning and feeding ground for marine mammals and birds (Stirling 1997), which suggests a strong link between the high phytoplankton biomass (Lewis et al. 1996, Mei et al. 2002), carbon production (Klein et al. 2002), silica and new production (Tremblay et al. 2002b) on the one hand, and the success of higher trophic levels on the other hand. Phytoplankton blooms produce large amounts of organic carbon, which is either exported to the pelagic food web or sinks out of the euphotic zone. The former leads to the production of renewable biological resources, and the latter may result in the sequestration of organic carbon at depth (Legendre 1990). Therefore, our second hypothesis was that a large fraction of the production in the NOW is transferred through the herbivorous food web rather than sinking out of the euphotic zone.

We tested these hypotheses during a multidisciplinary cruise on board the Canadian Coast Guard Ship (CCGS) 'Pierre Radisson' in the NOW, from April through July 1998. During the cruise, irradiance, nutrients, and size-fractionated phytoplankton biomass, 
production and settling rates were determined, together with physical characteristics of the water column.

\section{MATERIALS AND METHODS}

Sampling. Sampling was conducted from 7 April through 20 July 1998 (Fig. 1). CTD (conductivity, temperature and depth) profiles, incident PAR (photosynthetically available radiation, 400 to $700 \mathrm{~nm}$ ) on ship deck and over the euphotic zone (Mei et al. 2002), nutrients, including $\mathrm{NO}_{3}{ }^{-}+\mathrm{NO}_{2}{ }^{-}$(hereafter referred to as $\mathrm{N}$ ), $\mathrm{PO}_{4}{ }^{3-}$ (hereafter referred to as $\mathrm{P}$ ) and $\mathrm{Si}(\mathrm{OH})_{4}$ (hereafter referred to as Si) (Tremblay et al. 2002a,b) and phytoplankton samples (Mei et al. 2002) were taken, along with ice cover observations (Mundy \& Barber 2001). Surface incident irradiance $\left(E_{0}\right)$ was continuously monitored on deck with a LI-COR LI-190 SA cosine corrected flat sensor. The euphotic-zone depth was defined as the depth of $1 \%$ surface irradiance. Samples for phytoplankton biomass (chlorophyll $a_{\text {, }}$ hereafter referred to as chl) and phytoplankton production were collected at depths corresponding to 100, $45,30,20,10$ and $1 \%$ of surface irradiance, at stations located on several transects (Fig. 1b).

Phytoplankton biomass (chl) and production. Water samples (500 to $1000 \mathrm{ml}$ ) were filtered on Whatman GF/F ( $0.7 \mu \mathrm{m}$ pore size) and Nuclepore polycarbonate filters ( $5 \mu \mathrm{m}$ pore size) to obtain total and large chl as a measure of phytoplankton biomass $\left(B_{\mathrm{T}}\right.$ and $B_{\mathrm{L}}$, respectively). Chl concentrated on filters was extracted with $90 \%$ acetone in cold $\left(0\right.$ to $\left.5^{\circ} \mathrm{C}\right)$ and dark conditions for $24 \mathrm{~h}$. Chl in the extract was determined with a fluorometer (Turner Designs model 10) (Parsons et al. 1984). Biomass of small phytoplankton $\left(B_{\mathrm{S}}<5 \mu \mathrm{m}\right)$ was obtained by subtracting $B_{\mathrm{L}}$ from $B_{\mathrm{T}}$.

For phytoplankton production determination, water samples $(500 \mathrm{ml})$ from the euphotic zone were inoculated with $0.5 \mathrm{ml} \mathrm{NaH}^{14} \mathrm{CO}_{3}$ at $40 \mu \mathrm{Ci} \mathrm{ml}^{-1}$ and incubated on deck for $24 \mathrm{~h}$. The simulated in situ incubations started when the sun angle was the lowest of the day (Mingelbier et al. 1994). Irradiances in each incubator were adjusted with neutral density filters to approximate the irradiances at each sampling depth. During the incubation, surface water was continuously pumped through the incubators to maintain the incubation temperature close to that of the upper mixed layer, of which the depth (MLD) was established as that where the density increased by 0.01 , or 0.04 from surface (Mei et al. 2002). Incubations were stopped by filtering the samples on Whatman GF/F filters (production of total phytoplankton, $P_{\mathrm{POC}}$ or $P_{\mathrm{T}}$ ) or Nuclepore polycarbonate membrane filters (pore size: $5 \mu m_{i}$ production of large phytoplankton, $P_{\mathrm{L}}$ ). After filtration, the
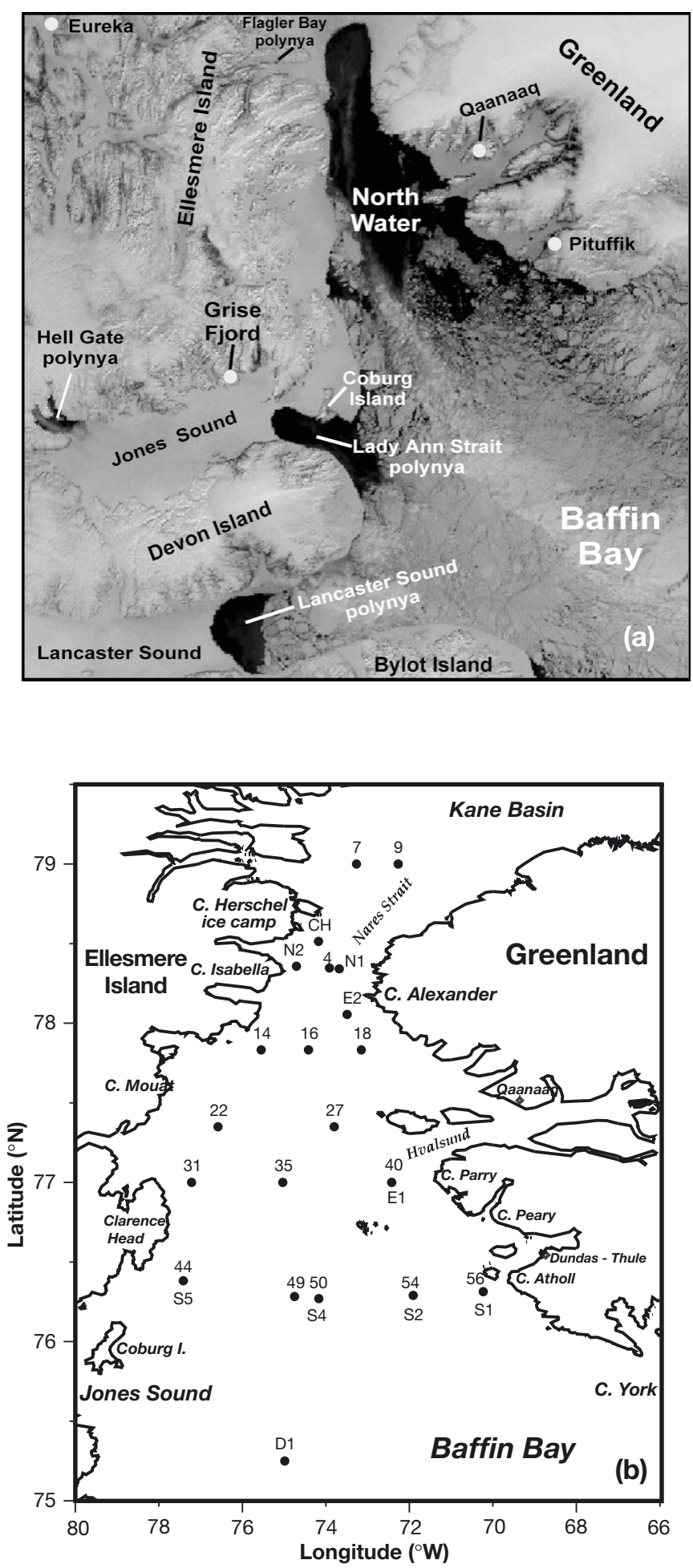

Fig. 1. (a) The satellite imagery of the North Water (NOW) polynya, taken on 10 May 1998 (courtesy of NOAA; image was processed by Dr. Martin Fortier). (b) Map of the NOW showing the locations of sampling stations. Stations marked with a number prefixed with a letter were mooring stations, sampled in July 1998. The other stations were sampled from April through June 1998 
filters were dropped in liquid scintillation vials, and inorganic ${ }^{14} \mathrm{C}$ was removed by acidifying the filters with $0.2 \mathrm{ml} 0.5 \mathrm{~N} \mathrm{HCl}$ and continuously shaking the vials for at least $12 \mathrm{~h}$ in a fume hood. This was followed by addition of Ecolume scintillation cocktail (ICN).

A subsample $(3 \mathrm{ml})$ of unfiltered incubated water was acidified with $0.5 \mathrm{ml} 6 \mathrm{~N} \mathrm{HCl}$ and shaken in the fume hood for at least $12 \mathrm{~h}$, followed by addition of $0.5 \mathrm{ml} 6 \mathrm{~N} \mathrm{NaOH}$ to neutralize the sample and addition of $10 \mathrm{ml}$ Ecolume. This provided the phytoplankton production of total organic carbon $\left(P_{\mathrm{TOC}}\right)$, i.e. the production of both particulate and dissolved organic carbon.

The samples with added Ecolume were kept in darkness and manually shaken several times during at least $48 \mathrm{~h}$ to ensure that all the radioactive materials on the filters were released into the Ecolume before scintillation counting. Samples were counted 2 to 3 times until counts were close in number. The measured radioactivity was transformed into production rates according to the JGOFS procedure (JGOFS 1996), using in situ total $\mathrm{CO}_{2}$, provided by Dr. L. Miller (Institute of Ocean Sciences, Sidney, British Columbia, Canada). $P_{\mathrm{DOC}}$ was obtained by subtracting $P_{\mathrm{POC}}$ from $P_{\mathrm{TOC}}$. The production of small phytoplankton $\left(<5 \mu \mathrm{m}, P_{\mathrm{S}}\right)$ was obtained by subtracting $P_{\mathrm{L}}$ from $P_{\mathrm{T}}$.

Areal phytoplankton production $\left(\mathrm{mg} \mathrm{C} \mathrm{m}^{-2} \mathrm{~d}^{-1}\right)$ and chl $\left(\mathrm{mg} \mathrm{m}^{-2}\right)$ were obtained by trapezoidal integration of volumetric values of phytoplankton production $\left(\mathrm{mg} \mathrm{C} \mathrm{m}^{-3} \mathrm{~d}^{-1}\right)$ and $\mathrm{chl}\left(\mathrm{mg} \mathrm{m}^{-3}\right)$ from the depth profiles over the euphotic zone. Phytoplankton production was corrected for light attenuation due to ice cover, as detailed in Mei et al. (2002). The assimilation number of phytoplankton $\left(P^{\mathrm{B}}, \mathrm{g} \mathrm{C} \mathrm{g} \mathrm{chl}^{-1} \mathrm{~h}^{-1}\right.$ or $\mathrm{g} \mathrm{C}_{\mathrm{g} \mathrm{chl}} \mathrm{C}^{-1}$ ) was obtained by dividing phytoplankton production by chl.

The model of Platt et al. (1980) was used to describe the relationship between $P^{\mathrm{B}}\left(\mathrm{g} \mathrm{C}_{\mathrm{g} \mathrm{chl}}{ }^{-1} \mathrm{~h}^{-1}\right)$ and daily averaged irradiance $\left(E_{0}, \mu \mathrm{mol}\right.$ photons $\left.\mathrm{m}^{-2} \mathrm{~s}^{-1}\right)$ received by the samples during incubation, so as to obtain $P_{\text {opt }}^{\mathrm{B}}$ (the light-saturated $P^{\mathrm{B}}$ for a phytoplankton production profile, as defined by Behrenfeld \& Falkowski 1997) when there was photoinhibition. Otherwise, the model of Jassby \& Platt (1976) was fitted to the data. The model of Jassby \& Platt (1976) was preferred when there was no photoinhibition because it has fewer parameters than the model of Platt et al. (1980) and therefore provided more stable estimates of parameters. Non-linear regressions were performed using the maximum likelihood procedure in Statistica (StatSoft).

Sinking rates (static) of phytoplankton cells taken from the depths of 50 and $1 \%$ surface irradiance were determined with settling columns (SETCOL) modified from Bien- fang (1981), with a height of $54 \mathrm{~cm}$, diameter of $9 \mathrm{~cm}$ and volume of $4.4 \mathrm{l}$. The SETCOLs were put in opaque sleeves (fixed with soft foam to isolate the SETCOLS from vibrations of the ship body) and set in a cold room $\left(\right.$ ca. $0^{\circ} \mathrm{C}$ ) onboard the ship. Water samples were transferred to SETCOLs immediately after sampling and kept for ca. $6 \mathrm{~h}$ in darkness, following the procedure of Bienfang (1981).

Statistics. Model II linear regressions were computed with either the ordinary least square (OLS) procedure, for predictive purposes, or reduced major axis procedure (RMA), for estimating functional relationships (Legendre \& Legendre 1998). In cases where the intercept was assumed to be 0 based on biological principles, the regression was forced through the origin. Path analyses were conducted to deconvolute the observed correlations among variables into direct and indirect causal relationships. Path coefficients were estimated by multiple ridge regressions after standardizing the raw data, and represented in path diagrams (Legendre \& Legendre 1998).

\section{RESULTS}

\section{Irradiance}

The time course variation of daily averaged irradiance is shown in Fig. 2. In general, incident PAR increased from April, when the sampling began, to early June and into July, except for low values in mid to late June associated with foggy conditions.

\section{Nutrients}

Detailed descriptions of spatial and temporal distributions of nutrients are given in Tremblay et al. (2002a), and summarized in Table 1. Ratios of Si to $\mathrm{N}$ and of $\mathrm{N}$ to $\mathrm{P}$ are shown in Figs. $3 \& 4$, respectively. In April, Si:N ratios ranged from 1.0 to 1.8. In May, parallel to the phytoplankton bloom and the associated $\mathrm{N}$ consump-

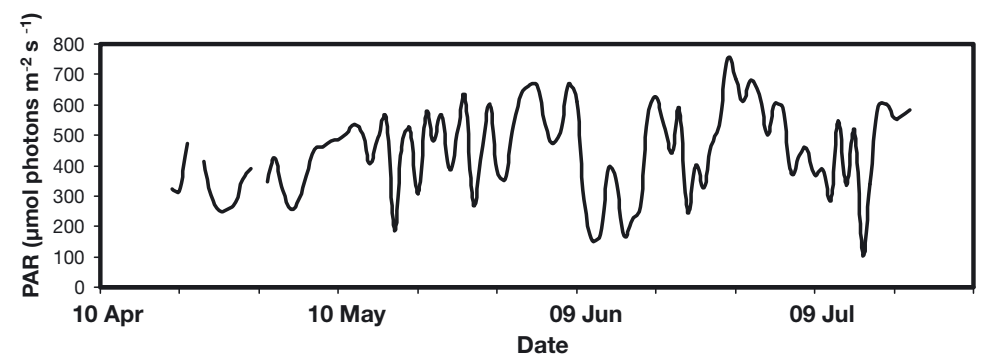

Fig. 2. Time series of PAR (photosynthetically available radiation) measured on deck, where samples for simulated in situ primary production were incubated 
Table 1. Average values and ranges of physical and chemical variables, and assimilation numbers of total and large phytoplankton. $E_{0}$ : surface incident irradiance; MLD: mixed-layer depth; $\mathrm{N}: \mathrm{NO}_{3}{ }^{-}+\mathrm{NO}_{2}{ }^{-} ; \mathrm{P}: \mathrm{PO}_{4}{ }^{3-} ; \mathrm{Si}: \mathrm{Si}(\mathrm{OH})_{4} ; P^{\mathrm{BT}}$ : assimilation number of total phytoplankton; $P^{\mathrm{BL}}$ : assimilation number of large phytoplankton; $P^{\mathrm{BT}}{ }_{\text {opt }}$ : light-saturated assimilation number of total phyto-

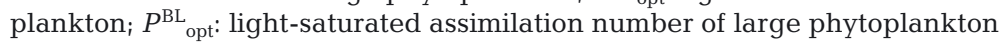

\begin{tabular}{|c|c|c|c|c|}
\hline \multirow{2}{*}{$\begin{array}{l}\text { Physical, chemical and } \\
\text { production variables }\end{array}$} & \multirow[b]{2}{*}{ April } & \multirow[b]{2}{*}{ May } & \multirow[b]{2}{*}{ June } & \multirow[b]{2}{*}{ July } \\
\hline & & & & \\
\hline$E_{0}\left(\mu \mathrm{mol}\right.$ photons $\left.\mathrm{m}^{-2} \mathrm{~s}^{-1}\right)$ & $94.9(47-139)$ & $321(142-495)$ & $304(51-521)$ & $300(45-517)$ \\
\hline $\operatorname{MLD}(\mathrm{m})$ & $51(20-114)$ & $41(13-54)$ & $14(5-25)$ & $9(5-17)$ \\
\hline $\mathrm{N}\left(\mathrm{mmol} \mathrm{m} \mathrm{m}^{-3}\right)$ & $9.9(7.9-10.7)$ & $7.2(0.3-10.2)$ & $2.9(<0.1-6.1)$ & $3.2(0.8-6.1)$ \\
\hline $\mathrm{P}\left(\mathrm{mmol} \mathrm{m}{ }^{-3}\right)$ & $1.3(0.8-1.5)$ & $1.21(0.7-1.5)$ & $0.8(0.3-1.4)$ & $0.78(0.5-1.1)$ \\
\hline $\mathrm{Si}\left(\mathrm{mmol} \mathrm{m}{ }^{-3}\right)$ & $14.3(7.6-17.4)$ & $19.9(4.8-23.0)$ & $8.7(1.0-24)$ & $5.9(2.6-11.4)$ \\
\hline$P^{\mathrm{BT}}\left(\mathrm{g} \mathrm{C} \mathrm{g} \mathrm{chl}^{-1} \mathrm{~h}^{-1}\right)$ & $15.7(2.5-44.7)$ & $11.3(6.7-24.2)$ & $10.5(1.5-27.5)$ & $5.7(1.4-10.0)$ \\
\hline$P^{\mathrm{BL}}\left(\mathrm{g} \mathrm{C} \mathrm{g} \mathrm{chl}^{-1} \mathrm{~h}^{-1}\right)$ & $17.3(3.6-40.8)$ & $11.8(6.6-14.7)$ & $9.0(1.2-21.8)$ & $4.7(1.3-8.6)$ \\
\hline$P^{\mathrm{BT}}{ }_{\text {opt }}\left(\mathrm{g} \mathrm{C} \mathrm{g} \mathrm{chl}^{-1} \mathrm{~h}^{-1}\right)$ & $2.1(0.8-4.3)$ & $1.3(0.9-1.6)$ & $1.0(0.8-1.7)$ & $0.8(0.3-1.0)$ \\
\hline$P_{\text {opt }}^{\mathrm{BL}}\left(\mathrm{g} \mathrm{C} \mathrm{g} \mathrm{chl}^{-1} \mathrm{~h}^{-1}\right)$ & $3.2(1.3-5.7)$ & $1.3(0.8-2.0)$ & $0.8(0.4-1.9)$ & $0.7(0.3-1.2)$ \\
\hline
\end{tabular}

tion, the Si:N ratio increased to $1.4-4.4$ at most stations. The ratio reached a remarkable value of 14.3 at Stn 54, southeast of the polynya, where the peak phytoplankton bloom was taking place. In June, Si:N ranged from 2.0 to 11.4 , with high values observed at stations with a sustained phytoplankton bloom, and low values in the southeast of the polynya, where the phytoplankton bloom declined. In July, the ratio was close to that of April, except for a high value of 4.2 at Stn N1 in northern Smith Sound, which is the outlet of the Arctic flow. At all stations and times, Si:N was $>1.0$.

The N:P ratios were rather uniformly distributed over the polynya in April, ranging from 5.5 to 8.6, except for the highest value of 10 at $\operatorname{Stn} 40$. In May, the ratio ranged from 5.1 to 6.9, except for the extremely low value of 0.8 at Stn 54 associated with the peak phytoplankton bloom and $\mathrm{N}$ depletion. In June, the ratio decreased at stations on the Greenland side of the polynya, and south of $77^{\circ} \mathrm{N}(0.5$ to 3$)$. Higher values of 3 to 8 were observed at stations north of $77^{\circ} \mathrm{N}$, and on the Canadian side of the polynya. In July, the ratios were rather uniformly distributed (3 to 5) over the polynya, the highest value of 15 being observed at Stn D68 in northern Baffin Bay. The N:P ratio was always $<15$, indicating that $\mathrm{P}$ was not the limiting element, by reference to the Redfield ratio of 16:1 (Redfield et al. 1963).

The observed variations in $\mathrm{Si}: \mathrm{N}$ and $\mathrm{N}: \mathrm{P}$ were mainly associated with $\mathrm{N}$ drawdown following the development of phytoplankton bloom. It appears that $\mathrm{N}$ was the most likely limiting nutrient in the NOW, by reference to the Redfield ratio (Redfield et al. 1963). Therefore, only $\mathrm{N}$ is included in the path analyses below.

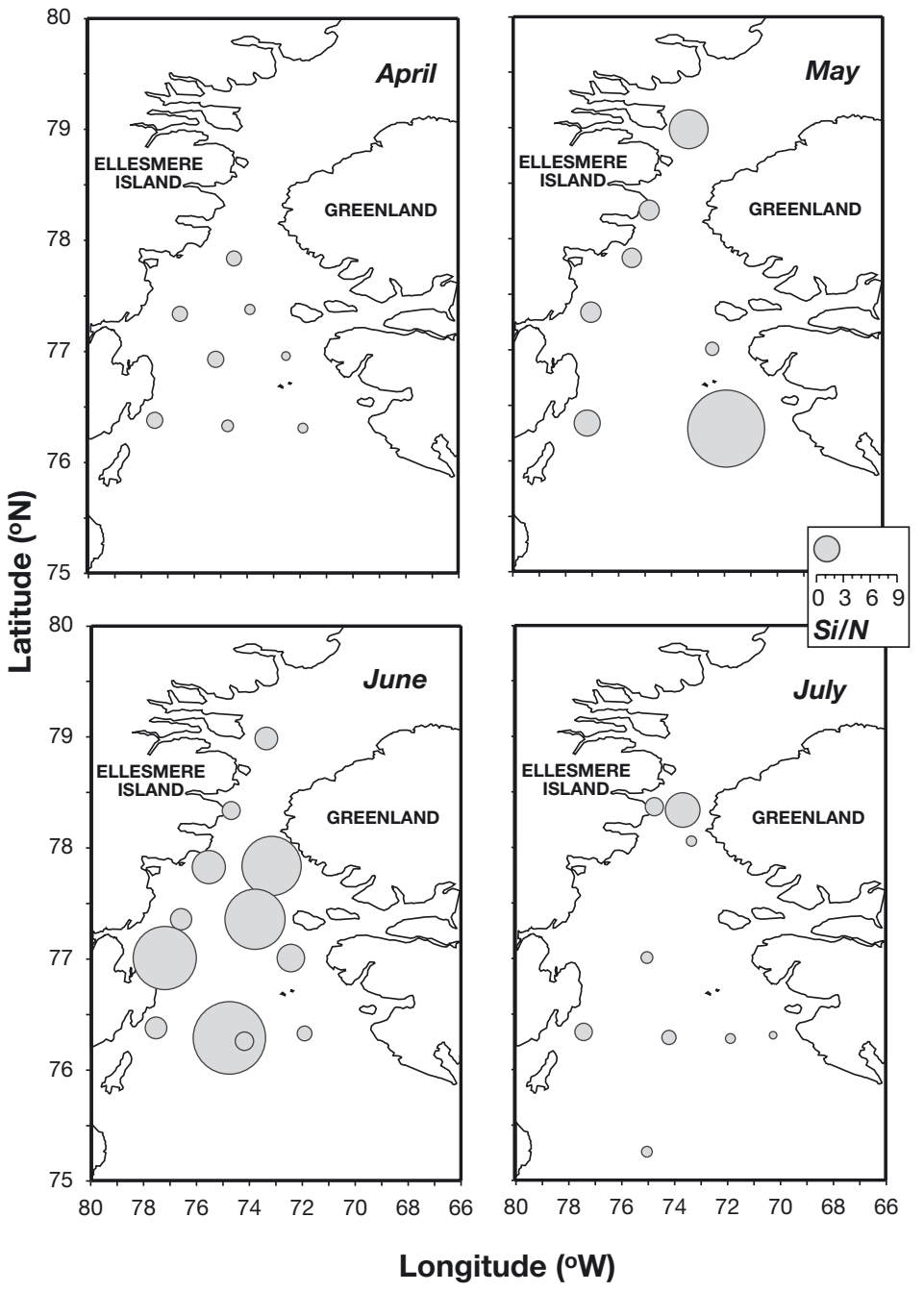

Fig. 3. Depth-integrated average concentration ratios (mol:mol) of $\mathrm{Si}\left(\mathrm{Si}(\mathrm{OH})_{4}\right)$ to $\mathrm{N}\left(\mathrm{NO}_{3}{ }^{-}+\mathrm{NO}_{2}^{-}\right)$in the euphotic zone from April to July 1998 


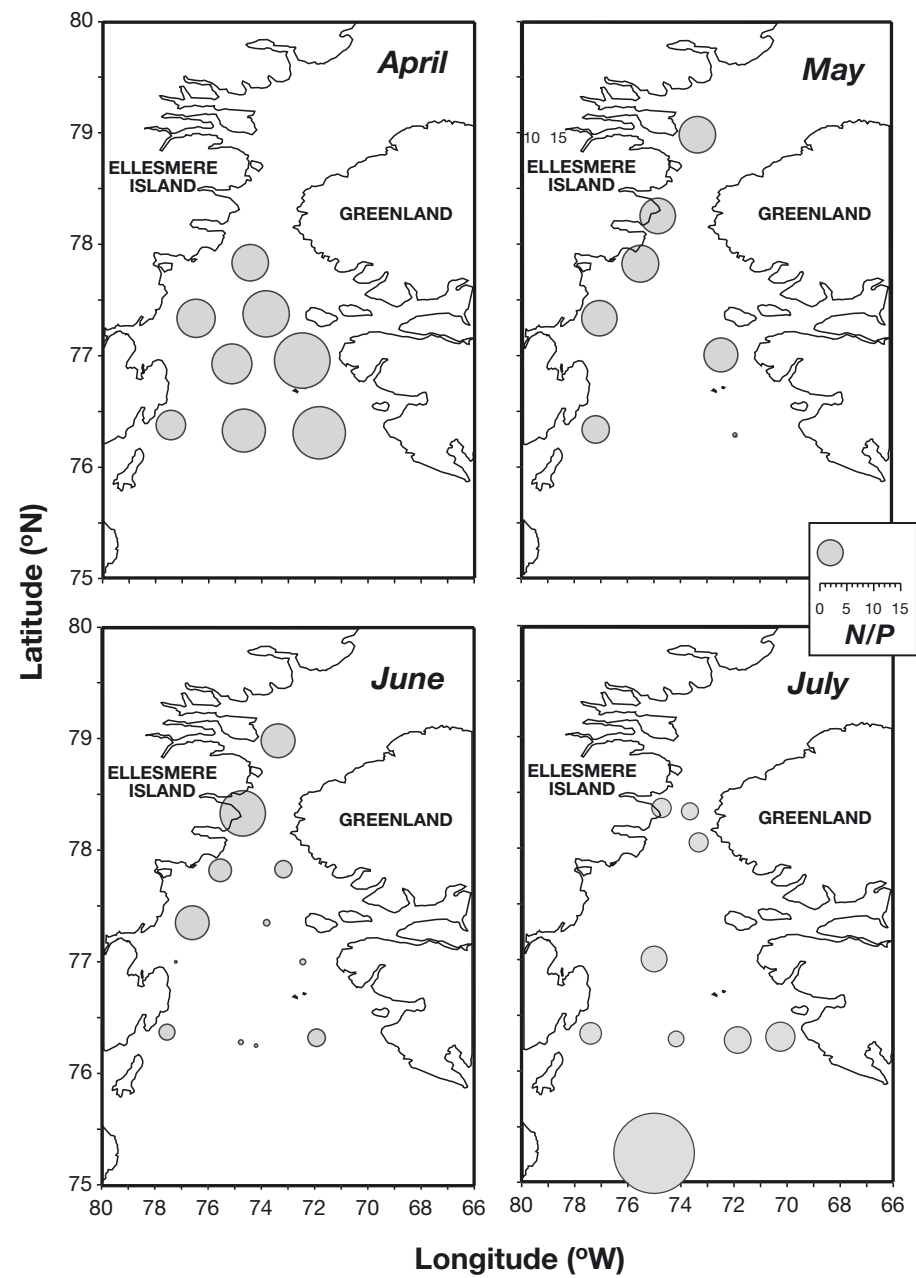

Fig. 4. Depth-integrated average concentration ratios of $\mathrm{N}$ $\left(\mathrm{NO}_{3}{ }^{-}+\mathrm{NO}_{2}^{-}\right)$to $\mathrm{P}\left(\mathrm{PO}_{4}{ }^{3-}\right)$ in the euphotic zone from April to July 1998

\section{Phytoplankton production}

Fig. 5 shows the spatial patterns of phytoplankton production during April through July. In April, high $P_{\text {TOC }}\left(0.4\right.$ to $\left.1 \mathrm{~g} \mathrm{C} \mathrm{m}^{-2} \mathrm{~d}^{-1}\right)$ was observed at stations on the Greenland side (e.g. Stns 27, 40 and 54), and very low values $\left(<0.2 \mathrm{~g} \mathrm{C} \mathrm{m}^{-2} \mathrm{~d}^{-1}\right)$ were observed on the Canadian side (Stns 22 and 44, Fig. 5a). In May, the highest $P_{\text {TOC }}$ occurred on the Greenland side, where the bloom reached its peak (Fig. 5b). The highest value $\left(6.0 \mathrm{~g} \mathrm{C} \mathrm{m}^{-2} \mathrm{~d}^{-1}\right)$ was observed at $\operatorname{Stn} 40$, followed by $4.8 \mathrm{~g} \mathrm{C} \mathrm{m}^{-2} \mathrm{~d}^{-1}$ at Stn 54 on the Greenland side. Values for northern stations (e.g. Stns 2, 7 and 14) were low $\left(<0.2 \mathrm{~g} \mathrm{C} \mathrm{m}^{-2} \mathrm{~d}^{-1}\right)$. Because of a strong storm, there are no data for Stns 18, 22 and 27. $P_{\text {TOC }}$ increased from May to June at the northern stations, and southern stations on the Canadian side (Fig. 5b,c). However, $P_{\text {TOC }}$ decreased by $\sim 50 \%$ at stations southeast of the polynya (e.g. Stn 40) on the
Greenland side from May to June. Further south, phytoplankton production decreased by nearly $100 \%$ from May to June. In July, $P_{\text {TOC }}$ at stations in the northern part of the polynya also decreased, and $P_{\text {TOC }}$ over the polynya was low $\left(<0.1\right.$ to $2.4 \mathrm{~g} \mathrm{C} \mathrm{m}^{-2} \mathrm{~d}^{-1}$, Fig. 5d). Therefore, the phytoplankton bloom ended in late June in the south, and in early July in the North of the polynya.

The relationships between $P_{\mathrm{TOC}}, E_{0}, \mathrm{~N}$, and water temperature are illustrated in Fig. 6. $P_{\mathrm{TOC}}>2 \mathrm{~g} \mathrm{C} \mathrm{m}^{-2}$ $\mathrm{d}^{-1}$ are associated with high $E_{0}$. Some of these high $P_{\text {TOC }}$ also appear to be associated with low $\mathrm{N}$, which is, in turn, associated with higher water temperature given the inverse relationship (Spearman $\mathrm{r}_{\mathrm{s}}=-0.85$, $\mathrm{n}=33, \mathrm{p}<0.01$ ) between $\mathrm{N}$ and water temperature (Fig. 6b). On the contrary, most $P_{\text {TOC }}<2 \mathrm{~g} \mathrm{C} \mathrm{m}^{-2} \mathrm{~d}^{-1}$ are associated with either $E_{0}<300 \mu \mathrm{mol}$ photons $\mathrm{m}^{-2}$ $\mathrm{s}^{-1}$, or high $\mathrm{N}$, but low water temperature (Fig. 6a,b).

\section{.}
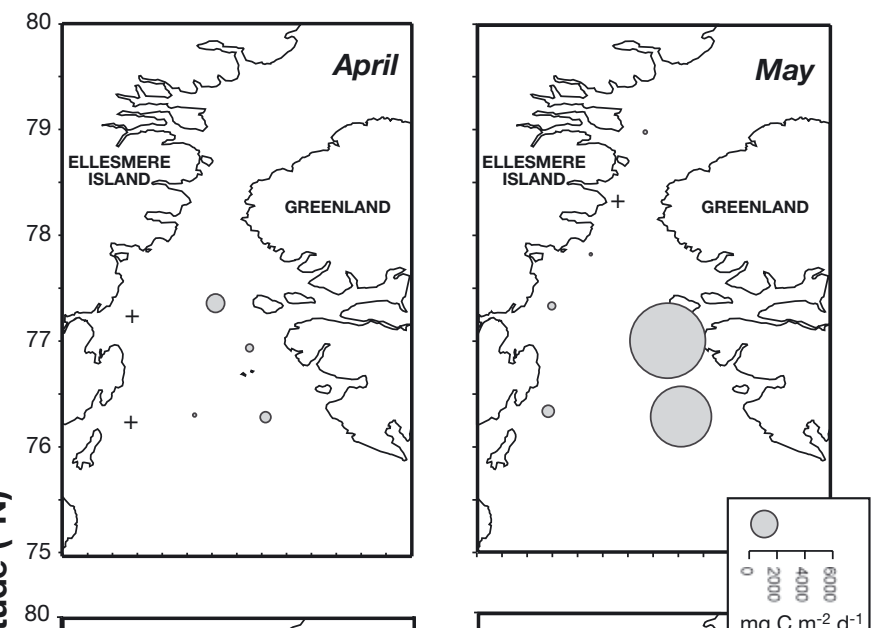

党
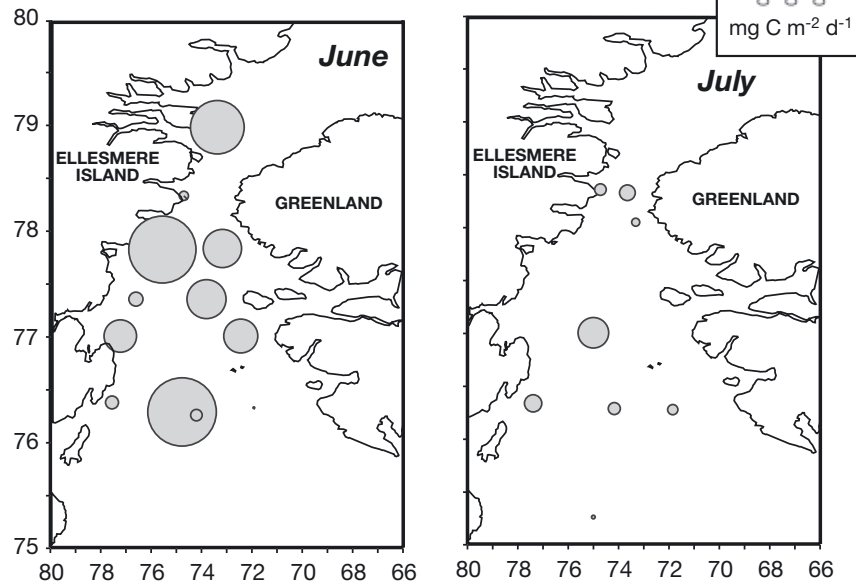

Longitude ( $\left.{ }^{\circ} \mathrm{W}\right)$

Fig. 5. Horizontal distribution of $P_{\text {TOC }}$ (production of total organic carbon) from April through July. The value of $P_{\mathrm{TOC}}$ is linearly proportional to the diameter of the bubbles. ' + ' indicates the positions of stations with total phytoplankton production values $<0.2 \mathrm{~g} \mathrm{C} \mathrm{m}^{-2} \mathrm{~d}^{-1}$ 

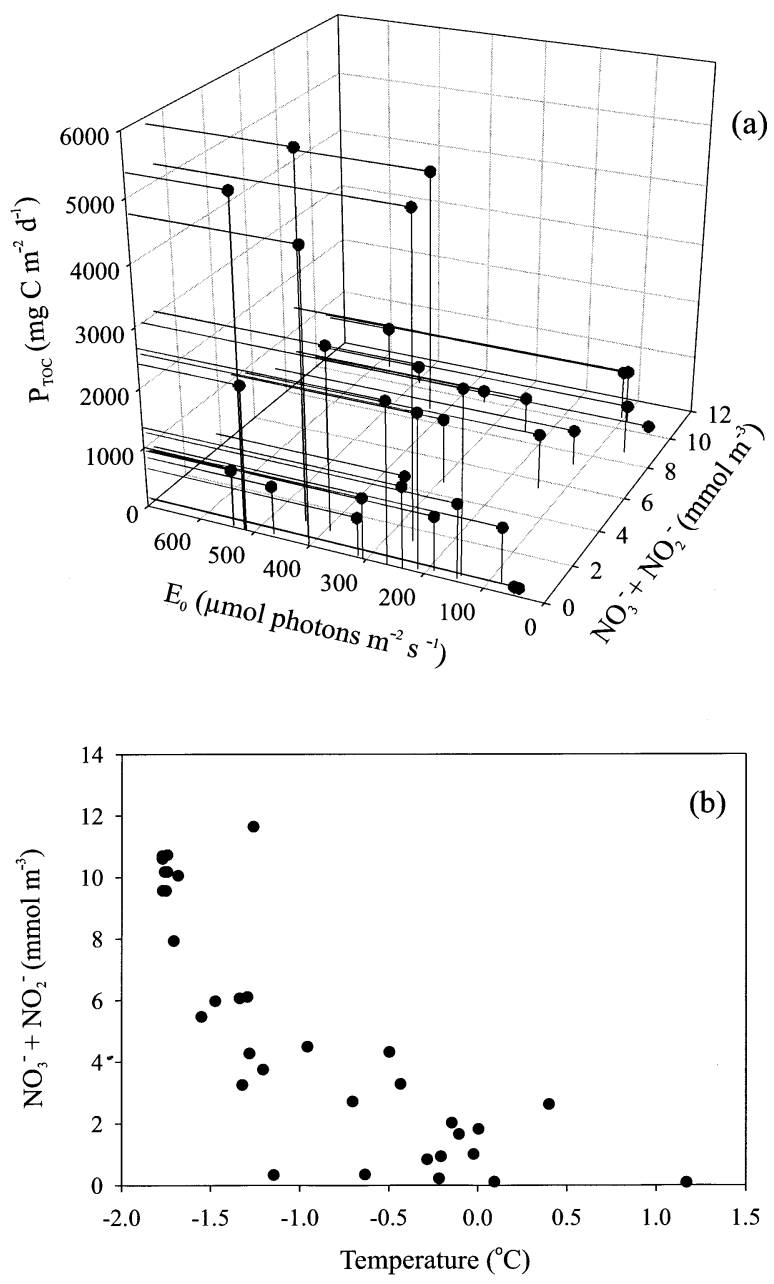

Fig. 6. (a) 3D plot of $P_{\text {TOC }}$ against $E_{0}$ (surface irradiance) and $\mathrm{N}$ $\left(\mathrm{NO}_{3}{ }^{-}+\mathrm{NO}_{2}{ }^{-}\right)$, and (b) scatter plot of the inverse relationship (Spearman $\mathrm{r}_{\mathrm{s}}=-0.85, \mathrm{n}=33, \mathrm{p}<0.01$ ) between $\mathrm{N}$ and water temperature

\section{Production and biomass of phytoplankton in different size fractions}

Relationship between phytoplankton production and chl

Areal chl integrated over the euphotic zone $\left(\mathrm{mg} \mathrm{m}^{-2}\right)$ explained a large fraction of the variance of $P_{\mathrm{TOC}}, P_{\mathrm{POC}}$ and $P_{\mathrm{DOC}}$ (Fig. 7). The respective regression (OLS) equations through the origin are listed in Table 2 (Eqs. 4 to 6). The highest slope among Eqs. (4) to (6) is for $P_{\mathrm{TOC}}$ on chl. Judging from the coefficients of determination, chl accounted for higher variability of $P_{\text {TOC }}$ than of $P_{\mathrm{POC}}$ or $P_{\mathrm{DOC}}$ separately. Similarly, phytoplankton production of large phytoplankton was largely explained by the corresponding biomass (Eq. 7 in Table 2).
Percent $P_{\mathrm{TOC}}$ as $P_{\mathrm{POC}}$ and $P_{\mathrm{DOC}}$

$P_{\text {POC }}$ was significantly related to $P_{\text {TOC }}$ (Fig. 8). The slopes $( \pm 95 \% \mathrm{CI})$ of the regressions (OLS) of $P_{\mathrm{POC}}$ on $P_{\mathrm{TOC}}$ are $0.9( \pm 0.23)$ and $0.5( \pm 0.21)$ for high $P_{\mathrm{TOC}}$ $\left(>2 \mathrm{~g} \mathrm{C} \mathrm{m}^{-2} \mathrm{~d}^{-1}\right)$ and low $P_{\mathrm{TOC}}\left(<2 \mathrm{~g} \mathrm{C} \mathrm{m}^{-2} \mathrm{~d}^{-1}\right)$, respectively (Eqs. $1 \& 2$ in Table 2), however, the difference is not significant at $\alpha=0.05$. A regression (OLS) through the origin was computed for the whole data set, resulting in an overall slope of 0.66 (Eq. 3 in Table 2).

The slope of the regression of $P_{\mathrm{L}}$ on $P_{\mathrm{T}}$ (Eq. 8 in Table 2) indicates that, on average, the production of large phytoplankton accounted for $81 \%$ of total
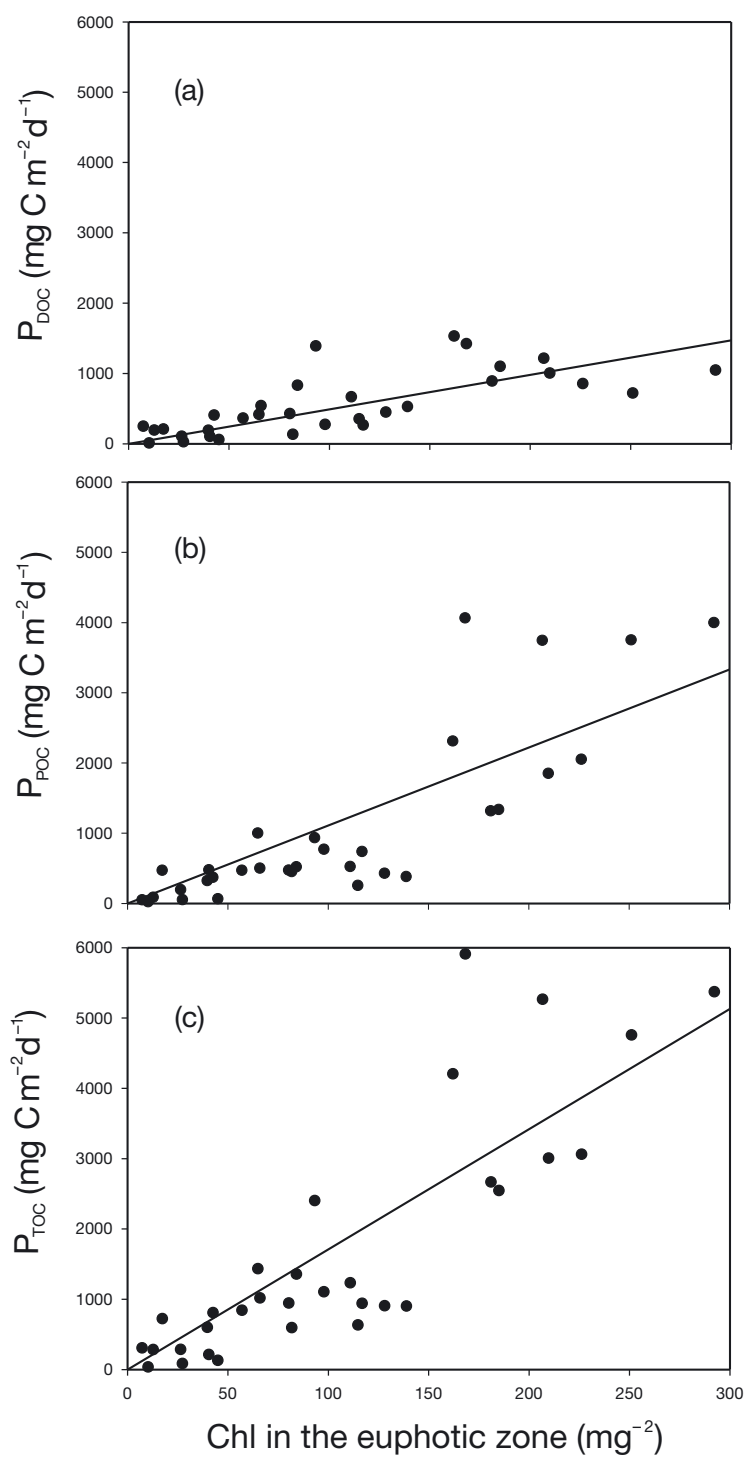

Fig. 7. Scatterplots and regressions of (a) $P_{\mathrm{DOC}}$ (b) $P_{\mathrm{POC}}$ and (c) $P_{\text {TOC }}$ on chl through the origin. Regression equations are given in Table 2 
phytoplankton production; however, the slope of the regression of $B_{\mathrm{L}}$ on $B_{\mathrm{T}}$ (Eq. 9, Table 2) indicates that the biomass of large phytoplankton accounted for $85 \%$ of total phytoplankton biomass, when integrated for the whole polynya during spring-summer.

\section{Relationships between $P_{\mathrm{L}}$ and $P_{\mathrm{S}}$ and $B_{\mathrm{L}}$ and $B_{\mathrm{S}}$}

The biomass of small phytoplankton increased linearly with that of large phytoplankton when $B_{\mathrm{L}}$ was $<160 \mathrm{mg}$ chl m${ }^{-2}$ (Fig. 9a; Eq. 10 in Table 2). Above $B_{\mathrm{L}}=160 \mathrm{mg} \mathrm{chl} \mathrm{m}{ }^{-2}, B_{\mathrm{S}}$ progressively decreased to undetectable levels as $B_{\mathrm{L}}$ approached $300 \mathrm{mg} \mathrm{m}^{-2}$ (Fig. 9a). Corresponding production of small phytoplankton increased linearly with that of large phytoplankton (Fig. 9b, Eq. 11 in Table 2). The 2 slopes are significantly lower than 1 , meaning that the biomass and production of small phytoplankton, and consequently their rate of biomass increase, were significantly lower than those of large phytoplankton.

\section{Light-saturated ( $\left.P_{\text {opt }}^{\mathrm{B}}\right)$ and depth-integrated rates $\left(P^{B}\right)$ of particulate phytoplankton production in different size fractions}

Path analyses (Fig. 10) were used to identify direct and indirect causal effects of $E_{0}, M L D, N$ and $P^{\mathrm{B}}$ opt on $P^{\mathrm{B}}$ integrated over the euphotic zone. Comparing the path diagrams for $P^{\mathrm{BT}}$ and $P^{\mathrm{BL}}$ shows that $P^{\mathrm{BT}}$ and $P^{\mathrm{BL}}$ responded differently to the independent variables (Fig. 10). The path coefficient from $E_{0}$ to $P^{\mathrm{BT}}$ is significant (Fig. 10a), but not that from $E_{0}$ to $P^{\mathrm{BL}}$ (Fig. 10b). The path coefficient from $\mathrm{N}$ to $P^{\mathrm{BT}}$ is significant, but not for that from $\mathrm{N}$ to $P^{\mathrm{BL}}$. However, $\mathrm{N}$ indirectly affects $P^{\mathrm{BL}}$ and $P^{\mathrm{BT}}$ similarly, i.e. through $P^{\mathrm{BL}}{ }_{\text {opt }}$ and $P^{\mathrm{BT}}{ }_{\text {opt, }}$ respectively.

\section{Sinking rates of phytoplankton}

The sinking rates of phytoplankton $(S)$ ranged from 0.1 to $0.7 \mathrm{~m} \mathrm{~d}^{-1}$, between April and July. The variations in sinking rates were small compared to those in phytoplankton biomass (Fig. 11).
The daily sinking fluxes of chl out of the euphotic zone $\left(F, \mathrm{mg} \mathrm{chl} \mathrm{m}^{-2} \mathrm{~d}^{-1}\right)$ were estimated by multiplying the mean concentration of chl integrated over the euphotic zone $\left(B_{\mathrm{V}}, \mathrm{mg} \mathrm{m}^{-3}\right)$ by $S\left(\mathrm{~m} \mathrm{~d}^{-1}\right)$. The mean sinking flux of total chl $\left(F_{\mathrm{T}}\right)$ was 0.35 (range: 0.01 to

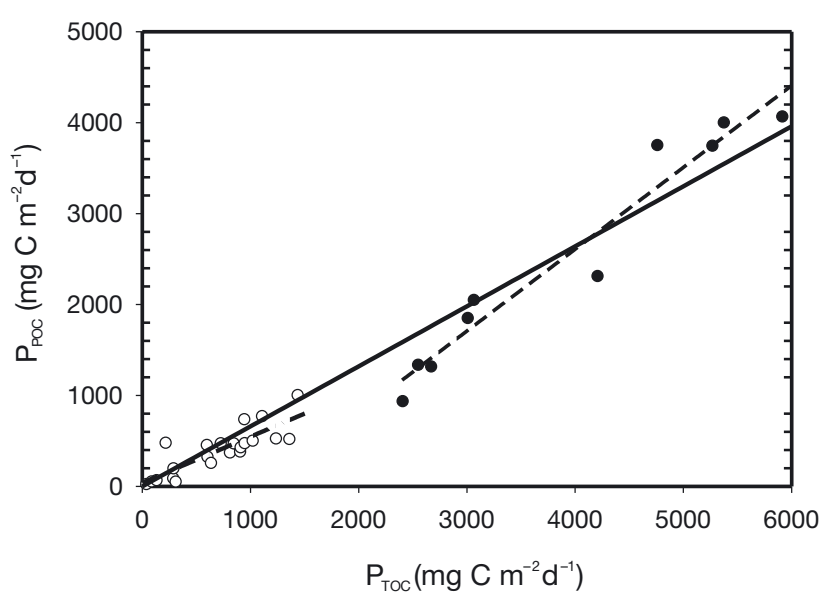

Fig. 8. Scatter plots and regressions of $P_{\mathrm{POC}}$ on $P_{\mathrm{TOC}}$. The data were separated in 2 groups, $P_{\mathrm{TOC}}>2 \mathrm{~g} \mathrm{C} \mathrm{m}^{-2} \mathrm{~d}^{-1}$ (•, Eq. 1) and $P_{\mathrm{TOC}}<2 \mathrm{~g} \mathrm{C} \mathrm{m}^{-2} \mathrm{~d}^{-1}$ (O; Eq. 2). Solid line: overall regression through the origin; Eq. 3 

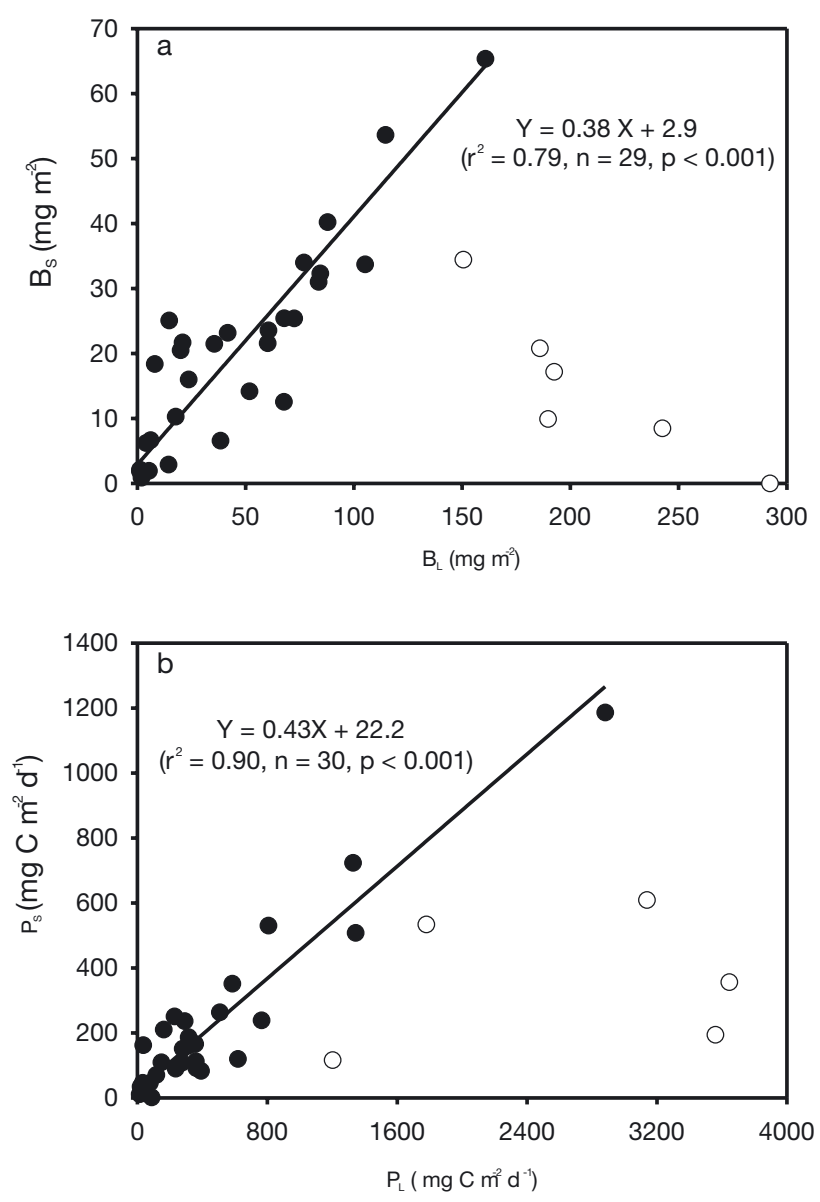

Fig. 9. Relationships between (a) the chl of small $\left(B_{\mathrm{S}}\right)$ and large phytoplankton $\left(B_{\mathrm{L}}\right)$, where the $B_{\mathrm{S}}$ starts to decrease when the $B_{\mathrm{L}}>160 \mathrm{mg} \mathrm{chl} \mathrm{m}^{-2}$ (clear circles), and (b) between production of small $\left(P_{\mathrm{S}}\right)$ and large phytoplankton $\left(P_{\mathrm{L}}\right)$. Clear circles were not included in Model II (reduced major axis [RMA] procedure) regression analyses

0.85), 1.38 (range: 0.02 to 5.0), 2.71 (range: 1 to 6 ) and 0.67 (range: 0.1 to 1.5 ) $\mathrm{mg} \mathrm{chl} \mathrm{m}^{-2} \mathrm{~d}^{-1}$, in April, May, June and July, respectively. The sinking flux for large phytoplankton $\left(F_{\mathrm{L}}\right)$ was $1.4(0.2$ to 5.2$), 2.8$ (1.1 to 6.8) and 0.6 (0.01 to 1.2$) \mathrm{mg} \mathrm{chl} \mathrm{m}^{-2} \mathrm{~d}^{-1}$, in May, June and July, respectively. Data for sinking rates of large phytoplankton are not available for April.

$F_{\mathrm{T}}$ and $F_{\mathrm{L}}$ were regressed (OLS) through the origin on the corresponding areal chl integrated over the euphotic zone ( $B_{\mathrm{T}}$ and $B_{\mathrm{L}}, \mathrm{mg} \mathrm{\textrm {m } ^ { - 2 }}$, respectively) (Eqs. $12 \& 13$ in Table 2). The slopes of the regressions show that 1.5 and $1.8 \%$ of the standing chl stocks of total and large phytoplankton in the euphotic zone, respectively, sank below the euphotic zone daily.
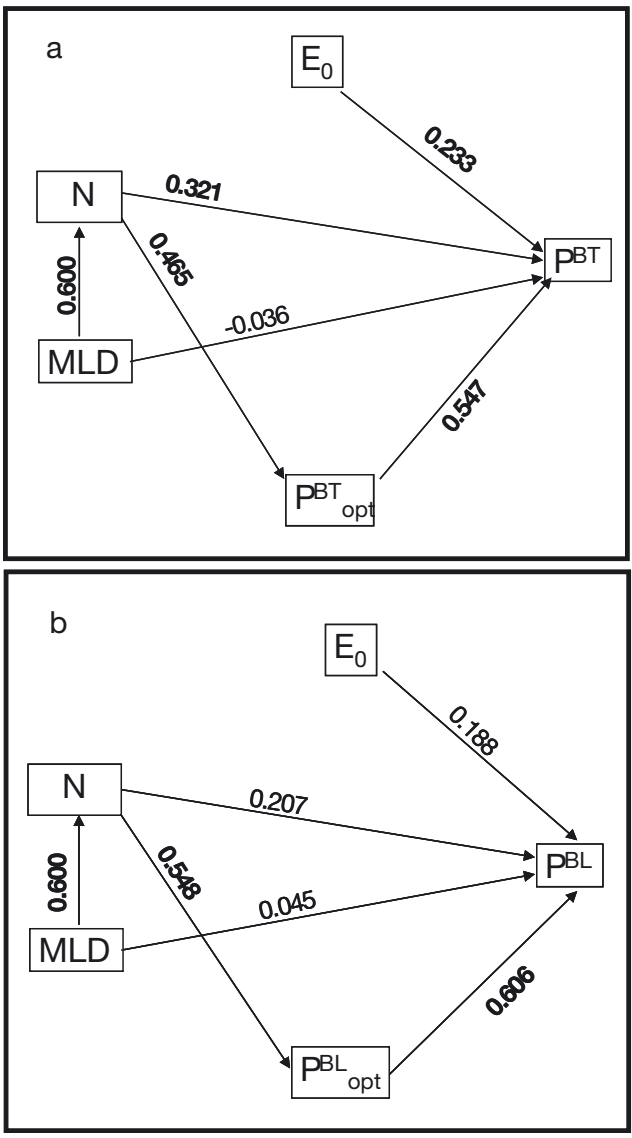

Fig. 10. Path analyses of $P^{\mathrm{B}}$ of (a) total $\left(P^{\mathrm{BT}}\right)$ and (b) large phytoplankton $\left(P^{\mathrm{BL}}\right)$ with respect to $\mathrm{N}\left(\mathrm{NO}_{3}^{-}+\mathrm{NO}_{2}^{-}\right), E_{0}$, MLD (mixed layer depth) and $P^{\mathrm{B}}$ opt of total $\left(P^{\mathrm{BT}}{ }_{\text {opt }}\right)$ or large phytoplankton $\left(P^{\mathrm{BL}}{ }_{\mathrm{opt}}\right)$, respectively. The arrows indicate the direction of the effect of one variable on another. The values associated to the arrows are the standardized path coefficients. Bold-type path coefficients are significant at $p<0.05$

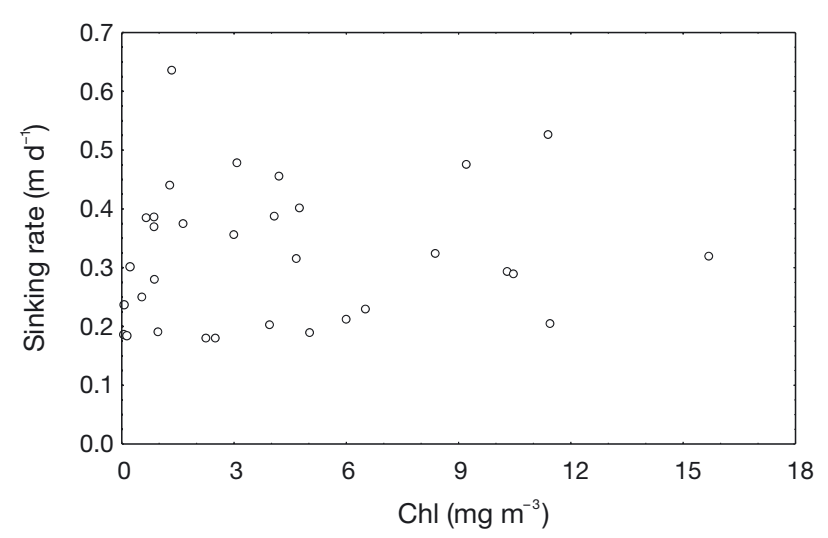

Fig. 11. Scatterplot of phytoplankton sinking rates $\left(\mathrm{m} \mathrm{d}^{-1}\right)$ versus mean integrated $\mathrm{chl}$ in the euphotic zone $\left(\mathrm{mg} \mathrm{m}^{-3}\right)$ 


\section{DISCUSSION}

\section{Differential responses of $\boldsymbol{P}^{\mathrm{B}}$ of large and small phytoplankton to physical and chemical properties in the water}

Behrenfeld \& Falkowski (1997) found that depthintegrated $P^{\mathrm{B}}$ is largely determined by light-saturated $P^{\mathrm{B}}, P_{\text {opt }}^{\mathrm{B}}$ over the World Ocean. $P_{\text {opt }}^{\mathrm{B}}$ in the present study was obtained from $24 \mathrm{~h}$ incubation, and therefore represents the photosynthetic characteristics of phytoplankton adapted to growth irradiance. This is different from the corresponding parameter of the photosynthesis versus irradiance relationship (Platt et al. 1980) obtained under short-term incubation $(<4 \mathrm{~h})$, which represents the photosynthetic characteristics of phytoplankton incubated under a different irradiance to that in their growth environment (Sakshaug et al. 1989, Cullen 1990).

In the present study, path analysis showed that $\mathrm{N}$ regulates $P^{\mathrm{B}}$ indirectly through its positive effect on $P^{\mathrm{B}}{ }_{\text {opt }}$ for both total and large phytoplankton (Fig. 10). This seems to be different from what was observed at the Bermuda Atlantic Time Series station (BATS, $\left.32^{\circ} 15^{\prime} \mathrm{N}, 65^{\circ} 45^{\prime} \mathrm{E}\right)$, where Johnson \& Howd (2000) found a negative correlation between $P^{\mathrm{B}}{ }_{\text {opt }}$ and nitrate concentration. They invoked several reasons to explain this, including multiple nutrient limitation, high nitrogen recycling and micronutrient limitation. However, high nitrate concentration in their data series covaried with the input of deep, cold water due to deepened mixed layer, which may imply a negative effect of temperature on $P^{\mathrm{B}}$ opt that would weaken the correlation between nitrate and $P^{\mathrm{B}}{ }_{\text {opt }}$.

The above mentioned dependence of $P^{\mathrm{B}}$ opt on nutrients in the NOW agrees with similar observations in the equatorial Pacific. The increased photosynthetic capacity caused by increased nutrient supply led to an almost 3-times increase in daily phytoplankton production there (Barber et al. 1996). Nutrient supply affects the quantum yield of photosynthesis (Sathyendranath et al. 1999), and the optical characteristics and subsequent carbon fixation of phytoplankton (BermanFrank \& Dubinsky 1999, and references therein). The studies cited above concern short-term incubations (4 to $6 \mathrm{~h}$ ), but similar mechanisms apply to long incubations (Cullen et al. 1990). Therefore, in the NOW, and probably most marine waters, the nutrient supply controls $P_{\text {opt }}^{\mathrm{B}}$ and thereby $P^{\mathrm{B}}$ integrated over the euphotic zone, by regulating the photosynthetic performance of phytoplankton, as observed in the western North Atlantic (Platt 1992).

Differences in the responses of $P^{\mathrm{BL}}$ and $P^{\mathrm{BS}}\left(P^{\mathrm{B}}\right.$ of small phytoplankton) to $E_{0}$ and $N$ can be inferred from the different responses of $P^{\mathrm{BT}}$ and $P^{\mathrm{BL}}$ to $E_{0}$ and N. As total phytoplankton includes both large and small phytoplankton, although dominated by large phytoplankton in the NOW, the significant causal effect from $\mathrm{N}$ to $P^{\mathrm{BT}}$ and non-significant causal effect from $\mathrm{N}$ to $P^{\mathrm{BL}}$ suggest that the $\mathrm{N}$ had significant causal effects on $P^{\mathrm{BS}}$. For the similar reason, the lower causal effects of $\mathrm{N}$ on $P^{\mathrm{BT}}{ }_{\text {opt }}\left(P^{\mathrm{B}}{ }_{\text {opt }}\right.$ of total phytoplankton), and of $P^{\mathrm{BT}}{ }_{\text {opt }}$ on $P^{\mathrm{BT}}$ than those of $\mathrm{N}$ on $P^{\mathrm{BL}}{ }_{\text {opt }}$, and of $P^{\mathrm{BL}}{ }_{\text {opt }}$ on $P^{\mathrm{BL}}$ suggest that the causal effects from $\mathrm{N}$ to $P^{\mathrm{BS}}{ }_{\text {opt }}\left(P^{\mathrm{B}}{ }_{\text {opt }}\right.$ of small phytoplankton), and of $P^{\mathrm{BS}}$ opt on $P^{\mathrm{BS}}$ were not significant. $\mathrm{N}$ limited $P^{\mathrm{BL}}$ indirectly by limiting their maximum photosynthetic capacity in the upper euphotic zone, which was not the case for small phytoplankton. Hence, $P^{\mathrm{BL}}$ opt was more N-dependent than $P_{\text {opt }}^{\mathrm{BS}}$.

Similarly, the significant effect of $E_{0}$ on $P^{\mathrm{BT}}$ (Fig. 10a) can be attributed to a light dependence of small phytoplankton, because the path coefficient from $E_{0}$ to $P^{\mathrm{BL}}$ (Fig. 10b) is not significant. This suggests that during the course of the phytoplankton bloom, the increased biomass of large phytoplankton took out the irradiance niche of small phytoplankton in the euphotic zone, which gave a competitive advantage to large phytoplankton. This conjecture is supported by the fact that the biomass and production of small phytoplankton decreased as large phytoplankton reached >150 mg chl $\mathrm{m}^{-2}$ (Fig. 9). This was not likely caused by $\mathrm{N}$ depletion, because the latter did not occur until $P_{\mathrm{L}}$ and $\mathrm{B}_{\mathrm{L}}$ reached their highest levels. In addition, small phytoplankton should be more competitive than large phytoplankton at taking up nutrients under low nutrient concentrations, given their higher surface to volume ratios. The $<1$ slopes of the regressions of $\mathrm{B}_{\mathrm{S}}$ on $\mathrm{B}_{\mathrm{L}}$ and $P_{\mathrm{S}}$ on $P_{\mathrm{L}}$ suggest that large phytoplankton had higher growth rates than their smaller counterparts. Therefore, we think that the development of large phytoplankton caused shading of small phytoplankton. Large phytoplankton exhibit higher quantum yield than small phytoplankton when nutrients are replete (Sathyendranath et al. 1999), which could explain why large phytoplankton were less light-dependent than small phytoplankton in the NOW. Figueiras et al. (1999) also observed a lack of light limitation when the phytoplankton community was dominated by large diatoms and Phaeocystis in the Weddell Sea in summer.

The potential effects of water temperature on $P^{\mathrm{B}}$ should be important. However, we were not able to continuously monitor water temperature during incubation, and the number of variables that could be included in path analyses is limited. Therefore, we did not try to investigate the effects of water temperature on $P^{\mathrm{B}}$ in path analyses. Direct assessment of the responses of $P^{\mathrm{B}}$ of small phytoplankton is difficult, because the biomass and production of small phytoplankton were obtained by differences between those of total and large phytoplankton. The resulting values 
of production and biomass of small phytoplankton are very small, resulting in larger errors.

However, the above conclusions are consistent with our first hypothesis that the photosynthetic characteristics of large phytoplankton respond to physical and chemical properties of the water column differently than those of small phytoplankton. Therefore, different physical and chemical properties will ultimately lead to variations in phytoplankton production in different size fractions.

\section{Partitioning of $\boldsymbol{P}_{\text {TOC }}$ into different size fractions $\left(P_{\mathrm{DOC}}, P_{\mathrm{L}}\right.$, and $\left.\boldsymbol{P}_{\mathrm{S}}\right)$ : biogeochemical significance}

The partitioning of carbon fixed into $P_{\mathrm{DOC}}$ and $P_{\mathrm{POC}}$ depending on $P_{\text {TOC }}$ level (Fig. 8), agrees with the crosssystem comparisons of Carlson et al. (1998), who found that in the eutrophic Ross Sea, $89 \%$ of the C fixed by phytoplankton was incorporated into POC and $11 \%$ into DOC, whereas in the oligotrophic Sargasso Sea, $86 \%$ of the inorganic C fixed was incorporated into DOC and $14 \%$ into POC. In the NOW, low production values were observed at stations with either one of the following unfavourable growth conditions: low irradiance, low temperature $\left(<-1^{\circ} \mathrm{C}\right)$, or low $\mathrm{N}$ (Fig. 6).

Baines \& Pace (1991) and Obernosterer \& Herndl (1995) observed that phytoplankton DOC exudation increased with increasing $\mathrm{N}: \mathrm{P}$ in the inorganic nutrients, as a response to $\mathrm{P}$ limitation. That led Karl et al. (2001) to hypothesize that the increased percentage of $P_{\text {DOC }}$ in the subtropical North Pacific Gyre resulted from a shift of the system from nitrogen to phosphorus limitation. However, N:P in the NOW was lower than the Redfield ratio, showing no evidence of P limitation (Fig. 4). On the contrary, $\mathrm{N}$ depletion was observed at stations southeast of the polynya by the end of June (Figs. 3 \& 4). In fact Obernosterer \& Herndl (1995) also observed increased extracellular DOC exudation at an $\mathrm{N}$ :P ratio of $<16$. Thus, high DOC production does not seem to be specifically associated with P limitation.

Overall, $P_{\text {DOC }}$ in the NOW made up a remarkably high fraction (34\%) of $P_{\mathrm{TOC}}$, and thus provided large amounts of substrate for the microbial food web. Karl et al. (1998) indicated that omission of $P_{\mathrm{DOC}}$ could result in a significant underestimation of global phytoplankton production, based on recent estimates of $P_{\mathrm{DOC}}$ and $P_{\mathrm{POC}}$ in the subtropical North Pacific Ocean. The higher slope of the regression of chl on $P_{\mathrm{TOC}}$ than that on $P_{\mathrm{POC}}$ alone, and the fact that chl accounted for higher variability of $P_{\mathrm{TOC}}$ than of $P_{\mathrm{POC}}$ alone (Eqs. $4 \& 5$ in Table 2), not only suggest that $P_{\mathrm{DOC}}$ is a significant fraction of $P_{\mathrm{TOC}}$, but also supports the argument of Baines \& Pace (1991) that DOC production is constrained by the total C fixed, instead of passive diffusion from phytoplankton cells.
There are few comparable data of $P_{\mathrm{DOC}}$ for Arctic waters (Wheeler et al. 1996, Gosselin et al. 1997, Vernet et al. 1998). The value of percent $P_{\mathrm{DOC}}$ in the present study $(34 \%$, derived from the slope of Eq. 3 in Table 2) agrees with those reported for the central Arctic Ocean (Wheeler et al. 1996, Gosselin et al. 1997), where $P_{\mathrm{DOC}}$ was $<40 \%$ of $P_{\mathrm{TOC}}$ at most stations, and as high as ca. $70 \%$ at a few stations between 75 and $85^{\circ} \mathrm{N}$. However, the highest observed $P_{\text {DOC }}$ there $\left(0.38 \mathrm{~g} \mathrm{C} \mathrm{m}^{-2} \mathrm{~d}^{-1}\right)$ is much lower than the highest in the NOW (>1.0 $\mathrm{g} \mathrm{C} \mathrm{m}^{-2} \mathrm{~d}^{-1}$ ).

In polar regions, $24 \mathrm{~h}$ daylight provides sufficient sea surface irradiance to enhance the photosynthetic fixation of carbon, while the loss of the carbon due to respiration in the night is much less than that at lower latitudes. Extremely high irradiance may increase the percent $P_{\mathrm{DOC}}$, especially when the $\mathrm{CO}_{2}: \mathrm{O}_{2}$ ratio is reduced because of continuous photosynthesis (Zlotnik \& Dubinsky 1989, Wood \& Van Valen 1990). Phytoplankton in nutrient-depleted waters may stop protein synthesis and growth, while the continuing photosynthetic carbon fixation favours DOC exudation (de Madariaga \& Fernandez 1990, Søndergaard et al. 2000).

DOC production in the NOW is remarkably high $\left(0.58 \mathrm{~g} \mathrm{C} \mathrm{m}^{-2} \mathrm{~d}^{-1}\right)$, and the absolute values of $P_{\mathrm{DOC}}$ may be among the highest reported in any ocean. This is largely because of the high $P_{\mathrm{TOC}}$. The contribution of DOC to deep export, via convective mixing in winter, depends on the temporal scale of its remineralization, which is not presently known in the NOW, nor the biodegradability of the produced DOC. The respiration of organic carbon back to $\mathrm{CO}_{2}$ within the microbial food web is highly dependent on temperature, generally more than phytoplankton production in polar waters (Pomeroy \& Deibel 1986, Yager \& Deming 1999, Rivkin \& Legendre 2001). Therefore, the high DOC production, which is associated with high $P_{\mathrm{TOC}}$ in the NOW, could result in a significant reduction of $\mathrm{CO}_{2}$ in the euphotic zone during the spring/summer season.

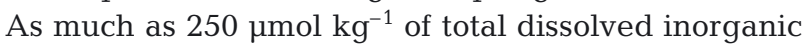
carbon (DIC) reduction in the upper water column in the NOW was observed by the end of the spring-summer phytoplankton bloom (Miller et al. 2002).

$P_{\text {POC }}$ in the present study (ca. $5 \mathrm{~g} \mathrm{C} \mathrm{m}^{-2} \mathrm{~d}^{-1}$ ) is among the highest values reported for polar seas. On the shelf and in the marginal ice zone of the Weddell Sea, Southern Ocean, the highest reported values are $2.6 \mathrm{~g}$ $\mathrm{C} \mathrm{m}^{-2} \mathrm{~d}^{-1}$ (Park et al. 1999). In the West Greenland Sea, a value of $3.2 \mathrm{~g} \mathrm{C} \mathrm{m}^{-2} \mathrm{~d}^{-1}$ was reported for the summer 1993 (Jensen et al. 1999). Both production and biomass of $P_{\mathrm{POC}}$ are dominated by large phytoplankton, as shown in Eqs. (8) \& (9) (Table 2). Therefore, most of the $P_{\mathrm{POC}}$ could be potentially exported to herbivorous food web, or towards depth. 


\section{Downward export of POC}

The low sinking rates observed in the NOW from April to July (0.1 to $0.7 \mathrm{~m} \mathrm{~d}^{-1}$, Fig. 11) probably resulted from the abundant supply of nutrients and $24 \mathrm{~h}$ daylight. These favoured the storage of energy in the cells, and hence their buoyancy adjustment, as suggested by Waite et al. (1992).

In April and May, our estimated daily chl sinking fluxes ( 0.01 to $6 \mathrm{mg} \mathrm{m}^{-2} \mathrm{~d}^{-1}$ ) are lower than, but of the same order of magnitude as, those obtained from short-term drifting sediment traps deployed below the euphotic zone during $24 \mathrm{~h}\left(<5 \mathrm{mg} \mathrm{chl} \mathrm{m}^{-2} \mathrm{~d}^{-1}\right.$, Michel et al. 2002). In June, these authors observed an increased chl flux $\left(6.1 \pm 5.8 \mathrm{mg} \mathrm{chl} \mathrm{m}^{-2} \mathrm{~d}^{-1}\right)$, and we also found increased chl fluxes to $2-4 \mathrm{mg} \mathrm{chl} \mathrm{m}^{-2} \mathrm{~d}^{-1}$ at stations where the flux was low in May $\left(<1 \mathrm{mg} \mathrm{chl} \mathrm{m}^{-2} \mathrm{~d}^{-1}\right)$, but none of our values reached their highest values of 16 and $19 \mathrm{mg} \mathrm{chl} \mathrm{m} \mathrm{m}^{-2} \mathrm{~d}^{-1}$ at Stations 49 and 18, respectively. In July, our values (average: 0.67 , range: 0.1 to $1.5 \mathrm{mg} \mathrm{m}^{-2} \mathrm{~d}^{-1}$ ) are close to the average of $1.1 \pm 0.7 \mathrm{mg}$ chl m $\mathrm{m}^{-2} \mathrm{~d}^{-1}$ of Michel et al. (2002).

The higher-settling flux from the drifting sediment trap than from the SETCOLs might have been caused by reduced turbulence in the latter. Indeed, moderate turbulence favors the formation of algal aggregates, which sink much faster than single cells (Jackson 1990, Kiørboe et al. 1998), though exceptions are reported (Kiørboe et al. 1998). Pesant et al. (2002) showed that wind-driven mixing in the upper water column of the Northeast Water polynya reduced the residence time of phytoplankton, thus favouring downward export. In the SETCOLs, algal aggregates were rare due to both the lack of turbulence and small sample volume. Nevertheless, our estimates of daily loss rates due to sinking were quite close to those reported in the productive Ross Sea polynya, where $2.3 \%$ of the phytoplankton standing stock sank out of the euphotic zone daily, when phytoplankton were dominated by slowsinking Phaeocystis antarctica (Asper \& Smith 1999).

The daily sinking fluxes of total and large phytoplankton, as a percentage of daily $P_{\mathrm{T}}$ and $P_{\mathrm{L}}$, averaged over the sampling area and period, can be estimated from the following equation:

$$
e=F / B \times \overline{P^{B}}
$$

where $e(\%)$ is the daily sinking flux as a percentage of daily $P_{\mathrm{POC}}$, and $\overline{P^{B}}\left(\mathrm{~g} \mathrm{C} \mathrm{g} \mathrm{chl}^{-1} \mathrm{~d}^{-1}\right)$ is the integrated mean $P^{\mathrm{B}}$ for the whole polynya and sampling season, estimated from the slopes of the regressions of $P_{\mathrm{T}}$ and $P_{\mathrm{L}}$ on chl for total (11.1 $\mathrm{g} \mathrm{C} \mathrm{g} \mathrm{chl}^{-1} \mathrm{~d}^{-1}$, Eq. 5 in Table 2) and large phytoplankton (10.6 $\mathrm{g} \mathrm{C} \mathrm{g} \mathrm{chl}^{-1} \mathrm{~d}^{-1}$, Eq. 7 in Table 2). $F / B$ is the daily chl flux as a percentage of standing stock, estimated from the slopes of regressions of $F$ on $B$ of total $(0.015$, or $1.5 \%$, Eq. 12 in
Table 2) and large phytoplankton (0.018, or $1.8 \%$, Eq. 13 in Table 2). The value of $e$ for total phytoplankton is thus $0.015 \times 11.1=16.7 \% \mathrm{~d}^{-1}$, and that for large phytoplankton is $0.018 \times 10.6=19.1 \% \mathrm{~d}^{-1}$. As $P_{\mathrm{L}}$ is $81 \%$ of $P_{\mathrm{T}}$ (Eq. 8 in Table 2), the daily sinking flux of large phytoplankton accounted for $81 \times 19.1 \% \mathrm{~d}^{-1}=15.5 \% \mathrm{~d}^{-1}$ of $P_{\mathrm{T}}\left(=P_{\mathrm{POC}}\right)$. This value is close to the e of total phytoplankton $\left(16.7 \% \mathrm{~d}^{-1}\right)$, and thus suggests that the downward export of small phytoplankton was negligible. Hence, the sinking cells were mostly large phytoplankton. Our values are close to 2 independent estimates of phytoplankton production export from the euphotic zone of the NOW, i.e. $20 \%$ based on both nutrient budgets (Tremblay et al. 2002b), and shortterm sediment traps (Michel et al. 2002).

\section{Carbon flux}

In order to test our second hypothesis, i.e. that a large fraction of the production in the NOW is transferred to the herbivorous food web rather than sinking to deep water ('Introduction'), we constructed a diagram of carbon fluxes (Fig. 12), based on our above estimates. Fig. 12 shows the temporally and spatially integrated partitioning of phytoplankton production and carbon fluxes in the NOW. During the sampling period, the mean $P_{\text {TOC }}$ was $1.7 \mathrm{~g} \mathrm{C} \mathrm{m}^{-2} \mathrm{~d}^{-1}$, of which

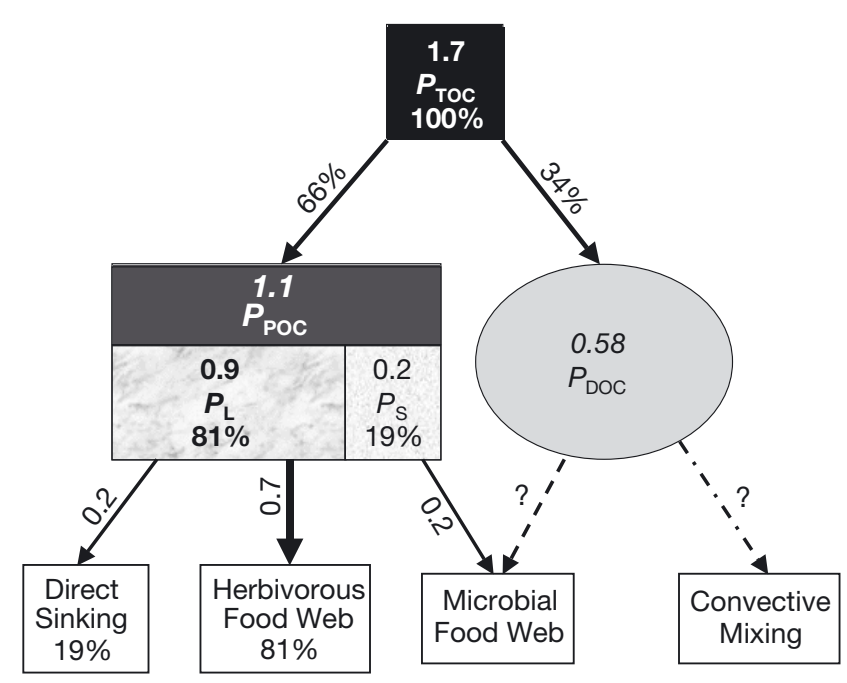

Fig. 12. Partitioning of $P_{\mathrm{TOC}}$ into $P_{\mathrm{DOC}}$ and $P_{\mathrm{POC}}$. The latter is partitioned into $P_{\mathrm{L}}$ and $P_{\mathrm{S}}$. $P_{\mathrm{L}}$ is either transferred to metazoans through the herbivorous food web, or exported to deep water by sinking. $P_{\mathrm{S}}$ is mostly channelled to the microbial food web, due to low loss to depth. $P_{\mathrm{DOC}}$ is either channelled to the microbial food web or exported to deep water by convective mixing in winter (there is no quantitative information for the latter as yet). The values are primary productions in different size fractions averaged over the whole polynya and sampling period. Rates are in $\mathrm{g} \mathrm{C} \mathrm{m}^{-2} \mathrm{~d}^{-1}$ 
$66 \%$ was produced as POC $\left(1.1 \mathrm{~g} \mathrm{C} \mathrm{m}^{-2} \mathrm{~d}^{-1}\right)$ and the remainder as DOC $\left(0.58 \mathrm{~g} \mathrm{C} \mathrm{m}^{-2} \mathrm{~d}^{-1}\right)$. We suggest that most of the $P_{\mathrm{POC}}$ of large phytoplankton was available to metazoans, with only ca. $19 \%\left(0.21 \mathrm{~g} \mathrm{C} \mathrm{m}^{-2} \mathrm{~d}^{-1}\right)$ sinking out of the euphotic zone. Part of the latter might have been remineralized back to $\mathrm{CO}_{2}$ during sinking; the extent of water-column remineralization depends on the activity of the microbial community and the residence time of particles in the water column before they reach the sea floor. Small phytoplankton contributed $16 \%\left(0.17 \mathrm{~g} \mathrm{C} \mathrm{m}^{-2} \mathrm{~d}^{-1}\right)$ of $P_{\mathrm{POC}}$, which were available to the microbial food web given that the downward export of small phytoplankton was negligible. Part of the production going to the microbial food web is eventually transferred to metazoans. Therefore, assuming that only large phytoplankton, which account for $81 \%$ of the $P_{\mathrm{POC}}$, sink out of the euphotic zone, about $66 \%(81 \% \times[100 \%-19.1 \%]=66 \%)$ of $P_{\mathrm{POC}}\left(0.73 \mathrm{~g} \mathrm{C} \mathrm{m}^{-2} \mathrm{~d}^{-1}\right)$ could be potentially transferred to the herbivorous food web. The high fraction of phytoplankton production available to metazoans could be one of the reasons why the NOW is a favourite spawning and feeding ground of large metazoans.

The above conclusion is supported by independent observations. For example, Ringuette et al. (2002) report that increased availability of chl in the NOW triggered the recruitment of Calanus copepod species, and the abundance of C. hyperboreus Stage CI peaked in the eastern sector in mid-May, corresponding to the peak phytoplankton bloom. Also, Karnovsky \& Hunt (2002) estimated that the dominant seabird (dovekies Alle alle) in the polynya consumed ca. 5 to $14 \%$ of new phytoplankton production during spring-summer of 1998.

In polar regions, the underwater irradiance depends on ice concentration, while nutrients depend on water column stability and regional circulation. Ice concentration, water column stability and circulation will be affected by climate change. Our results could therefore be used in models to predict how biogeochemical processes would respond to the changes in physical and chemical properties of the water column induced by climate change.

Acknowledgements. We thank Profs. W. F. Vincent and L. Fortier (Université Laval, Canada), for valuable comments and suggestions. Prof. P. Minnett (University of Miami, USA) provided access to the on-deck PAR data set. Prof. P. Legendre (University of Montreal, Canada) provided his computer program for Model II linear regression analyses. We appreciated the assistance and encouragement from colleagues in the NOW project and the officers and crew of the CCGS 'Pierre Radisson' at the time of sampling and data acquisition in the field. Special thanks are due to Ms. M. Robert for her efficient work at CTD profiling during the whole cruise. The study was funded by grants from the Natural Sciences and Engineering Research Council of Canada to L.L., Y.G. and
M.G., and received logistical support from the Polar Continental Shelf Project (Energy, Mines and Resources Canada) and the Canadian Coast Guard. This is a contribution to the research program of GIROQ (Groupe interuniversitaire de recherches océanographiques du Québec).

\section{LITERATURE CITED}

Asper VL, Smith WO Jr (1999) Particle fluxes during austral spring and summer in the southern Ross Sea, Antarctica. J Geophys Res 104:5345-5359

Baines SB, Pace ML (1991) The production of dissolved organic matter by phytoplankton and its importance to bacteria: patterns across marine and freshwater systems. Limnol Oceanogr 36:1078-1090

Barber RT, Sanderson MP, Lindley ST, Chai F, Newton J, Trees CC, Foley DG, Chavez FP (1996) Primary productivity and its regulation in the Equatorial Pacific during and following the 1991-1992 El Nino. Deep-Sea Res II 43: 933-969

Behrenfeld MJ, Falkowski PG (1997) A consumer's guide to phytoplankton primary productivity models. Limnol Oceanogr 42:1479-1491

Berman-Frank I, Dubinsky Z (1999) Balanced growth in aquatic plants: myth or reality? BioScience 47:29-37

Bienfang PK (1981) SETCOL - a technologically simple and reliable method for measuring phytoplankton sinking rates. Can J Fish Aquat Sci 38:1289-1294

Bury SJ, Boyd PW, Preston T, Savidge G, Owens NJP (2001) Size-fractionated primary production and nitrogen uptake during a North Atlantic phytoplankton bloom: implications for carbon export estimates. Deep-Sea Res I 48: 689-720

Carlson CA, Ducklow HW, Hansell DA, Smith WO Jr (1998) Organic carbon partitioning during spring phytoplankton blooms in the Ross Sea polynya and the Sargasso Sea. Limnol Oceanogr 43:375-386

Chisholm SW (1992) Phytoplankton size. In: Falkowski PG, Woodhead AD (eds) Primary productivity and biogeochemical cycles in the sea. Plenum Press, New York, p 213-237

Cota GF, Pomeroy LR, Harrison WG, Jones EP, Peters F, Sheldon WM Jr, Weingartner TR (1996) Nutrients, primary production and microbial heterotrophy in the southeastern Chukchi Sea: Arctic summer nutrient depletion and heterotrophy. Mar Ecol Prog Ser 135:247-258

Cullen JJ (1990) On models of growth and photosynthesis in phytoplankton. Deep-Sea Res A 37:667-683

Dauchez S, Legendre L, Fortier L, Levasseur M (1996) Nitrate uptake by size-fractionated phytoplankton on the Scotian Shelf (Northwest Atlantic): spatial and temporal variability. J Plankton Res 18:577-595

de Madariaga I, Fernandez E (1990) Photosynthetic carbon metabolism of size-fractionated phytoplankton during an experimental bloom in marine microcosms. J Mar Biol Assoc UK 70:531-543

Falkowski P, Barber RT, Smetacek V (1998) Biogeochemical controls and feedbacks on ocean primary production. Science 281:200-206

Figueiras FG, Arbones B, Estrada M (1999) Implications of bio-optical modeling of phytoplankton photosynthesis in Antarctic waters: further evidence of no light limitation in the Bransfield Strait. Limnol Oceanogr 44:1599-1608

Finkel ZE, Irwin A (2000) Modeling size-dependent photosynthesis: light absorption and the allometric rule. J Theor Biol 204:361-369 
Fortier L, Le Fèvre J, Legendre L (1994) Export of biogenic carbon to fish and to the deep ocean: the role of large planktonic microphages. J Plankton Res 16:809-839

Gosselin M, Levasseur M, Wheeler PA, Horner RA, Booth B (1997) New measurements of phytoplankton and ice algal production in the Arctic Ocean. Deep-Sea Res II 44: 1623-1644

Jackson GA (1990) A model of the formation of marine algal flocs by physical coagulation processes. Deep-Sea Res A 37:1197-1211

Jassby AD, Platt T (1976) Mathematical formulation of the relationship between photosynthesis and light for phytoplankton. Limnol Oceanogr 21:540-547

Jensen HM, Pedersen L, Burmeister A, Hansen BW (1999) Pelagic primary production during summer along 65 to 72 degree N off West Greenland. Polar Biol 21:269-278

JGOFS (1996) Protocols for the Joint Global Ocean Flux Study (JGOFS) core measurements. Report No. 19. Scientific Committee on Oceanic Research, International Council of Scientific Union, Bergen

Johnson Z, Howd P (2000) Marine photosynthetic performance forcing and periodicity for the Bermuda Atlantic time series, 1989-1995. Deep-Sea Res I 47:1485-1512

Karl DM, Hebel DV, Bjoerkman K, Letelier RM (1998) The role of dissolved organic matter release in the productivity of the oligotrophic North Pacific Ocean. Limnol Oceanogr 43:1270-1286

Karl DM, Bjorkman KM, Dore JE, Fujieki L, Hebel DV, Houlihan T, Letelier RM, Tupas LM (2001) Ecological nitrogento-phosphorus stoichiometry at station ALOHA. Deep-Sea Res II 48:1529-1566

Karnovsky N, Hunt G Jr (2002) Estimation of carbon flux to dovekies (Alle alle) in the North Water. Deep-Sea Res II 49:5117-5130

Kiørboe T, Tiselius P, Mitchell-Innes B, Hansen JLS, Visser AW, Mari X (1998) Intensive aggregate formation with low vertical flux during an upwelling-induced diatom bloom. Limnol Oceanogr 43:104-116

Klein K, LeBlanc B, Mei ZP, Bereta R and 12 others (2002) Phytoplankton biomass, production and potential export in the North Water. Deep-Sea Res II 49:4983-5002

Kristiansen S, Farbrot T, Wheeler PA (1994) Nitrogen cycling in the Barents Sea- seasonal dynamics of new and regenerated production in the marginal ice zone. Limnol Oceanogr 39:1630-1642

Legendre L (1990) The significance of microalgal blooms for fisheries and for the export of particulate organic carbon in oceans. J Plankton Res 12:681-699

Legendre L, Le Fèvre J (1989) Hydrodynamical singularities as control of recycled versus export production in oceans. In: Berger WH, Smetacek VS, Wefer G (eds) Productivity of the ocean: present and past. John Wiley \& Sons, New York, p 49-63

Legendre L, Rassoulzadegan F (1996) Food-web mediated export of biogenic carbon in oceans: hydrodynamic control. Mar Ecol Prog Ser 145:179-193

Legendre P, Legendre L (1998) Numerical ecology, 2nd edn. Elsevier, Amsterdam

Lewis EL, Ponton D, Legendre L, LeBlanc B (1996) Springtime sensible heat, nutrients and phytoplankton in the Northwater polynya, Canadian Arctic. Cont Shelf Res 16: 1775-1792

Mei Z-P, Legendre L, Gratton Y, Tremblay JÉ and 8 others (2002) Physical control of spring-summer phytoplankton dynamics in the North Water, April-July 1998. Deep-Sea Res II 49:4959-4982

Michel C, Gosselin M, Nozais C (2002) Preferential sinking export of biogenic silica during the spring and summer in the North Water polynya (northern Baffin Bay): temperature or biological control? J Geophys Res 107:1-1-14

Miller LA, Yager P, Erickson KA, Amiel D and 8 others (2002) Carbon distributions and fluxes in the North Water, 1998 and 1999. Deep-Sea Res II 49:5151-5170

Mingelbier M, Klein B, Claereboudt MR, Legendre L (1994) Measurement of daily primary production using $24 \mathrm{~h}$ incubations with the ${ }^{14} \mathrm{C}$ method: a caveat. Mar Ecol Prog Ser 113:301-309

Mundy CJ, Barber DG (2001) On the relationship between the spatial pattern of sea ice type and the mechanisms which create and maintain the North Water (NOW) polynya. Atmos-Ocean 39:327-341

Obernosterer I, Herndl GJ (1995) Phytoplankton extracellular release and bacterial growth: dependence on the inorganic N:P ratio. Mar Ecol Prog Ser 116:247-257

Park GM, Yang SR, Kang SH, Chung KH, Shim JH (1999) Phytoplankton biomass and primary production in the marginal ice zone of the northwestern Weddell Sea during austral summer. Polar Biol 21:251-261

Parsons TR, Maita Y, Lalli CM (1984) A manual of chemical and biological methods for seawater analyses. Pergamon Press, Oxford, $173 \mathrm{p}$

Pesant S, Legendre L, Gosselin M, Smith REH, Kattner G, Ramseier RO (1996) Size-differential regimes of phytoplankton production in the Northeast Water Polynya $\left(77^{\circ}-\right.$ $\left.81^{\circ} \mathrm{N}\right)$. Mar Ecol Prog Ser 142:75-86

Pesant S, Legendre L, Gosselin M, Bauerfeind E, Budéus G (2002) Wind-triggered events of phytoplankton downward flux in the Northeast Water Polynya. J Mar Syst 31: $261-278$

Platt T (1992) Nutrient control of phytoplankton photosynthesis in the western North Atlantic. Nature 356:229-231

Platt T, Gallegos CL, Harrison WG (1980) Photoinhibition of photosynthesis in natural assemblages of marine phytoplankton. J Mar Res 38:687-701

Platt T, Harrison WG, Lewis MR, Li WKW, Sathyendranath S, Smith RE, Vézina AF (1989) Biological production of the oceans: the case for a consensus. Mar Ecol Prog Ser 52: $77-88$

Pomeroy LR (1997) Primary production in the Arctic Ocean estimated from dissolved oxygen. J Mar Syst 10:1-8

Pomeroy LR, Deibel D (1986) Temperature regulation of bacterial activity during the spring bloom in Newfoundland coastal waters. Science 233:359-361

Redfield AC, Ketchum BH, Richards FA (1963) The influence of organisms on the composition of sea water. In: Hill MN (ed) The sea, Vol 2. Interscience, New York, p 26-77

Ringuette M, Fortier L, Fortier M, Runge JA, Bélanger $S$, Larouche P, Weslawski JM, Kwasniewski S (2002) Advanced recruitment and accelerated population development in Arctic calanoid copepods of the North Water. Deep-Sea Res II 49:5081-5099

Rivkin RB, Legendre L (2001) Biogenic carbon cycling in the upper ocean: effects of microbial respiration. Science 291: 2398-2400

Sakshaug E, Kiefer DA, Andersen K (1989) A steady-state description of growth and light absorption in the marine planktonic diatom Skeletonema costatum. Limnol Oceanogr 34:198-205

Sathyendranath S, Longhurst A, Caverhill CM, Platt T (1995) Regionally and seasonally differentiated primary production in the North Atlantic. Deep-Sea Res I 42: 1773-1802

Sathyendranath S, Stuart V, Irwin BD, Maass H, Savidge G, Gilpin L, Platt T (1999) Seasonal variations in bio-optical 
properties of phytoplankton in the Arabian Sea. Deep-Sea Res II 46:633-653

Søndergaard M, Williams PJL, Cauwet G, Riemann B, Robinson C, Terzic S, Woodward EMS, Worm J (2000) Net accumulation and flux of dissolved organic carbon and dissolved organic nitrogen in marine plankton communities. Limnol Oceanogr 45:1097-1111

Stirling I (1980) The biological importance of polynyas in the Canadian Arctic. Arctic 33:303-315

Stirling I (1997) The importance of polynyas, ice edges and leads to marine mammals and birds. J Mar Syst 10:9-21

Tremblay JÉ, Legendre L (1994) A model for the size fractionated biomass and production of marine phytoplankton. Limnol Oceanogr 39:2004-2014

Tremblay JÉ, Legendre L, Rivkin RB, Therriault JC (1997a) Estimation of $f$-ratios in oceans based on phytoplankton size structure. Limnol Oceanogr 42:595-601

Tremblay JÉ, Legendre L, Therriault JC (1997b) Size-differential effects of vertical stability on the biomass and production of phytoplankton in a large estuarine system. Estuar Coast Shelf Sci 45:415-431

Tremblay, JÉ, Legendre L, Klein B, Therriault JC (2000) Sizedifferential uptake of nitrogen and carbon in a marginal sea (Gulf of St. Lawrence, Canada): significance of diel periodicity and urea uptake. Deep-Sea Res II 47:489-518

Tremblay JÉ, Gratton Y, Carmack EC, Payne CD, Price NM (2002a) Impact of the large-scale Arctic circulation and the

Editorial responsibility: Otto Kinne (Editor),

Oldendorf/Luhe, Germany
North Water Polynya on nutrient inventories in Baffin Bay. J Geophys Res 107:26-1-14

Tremblay JÉ, Gratton Y, Fauchot J, Price NM (2002b) Climate and oceanic forcing of new, net, and diatom production in the North Water. Deep-Sea Res II 49:4927-4946

Vernet M, Matrai PA, Andreassen I (1998) Synthesis of particulate and extracellular carbon by phytoplankton at the marginal ice zone in the Barents Sea. J Geophys Res 103: 1023-1037

Waite AM, Thompson PA, Harrison PJ (1992) Does energy control the sinking rates of marine diatoms? Limnol Oceanogr 37:468-477

Walsh JJ (1989) Arctic carbon sinks: present and future. Global Biogeochem Cycles 3:393-411

Wheeler PA, Gosselin M, Sherr E, Thibault D, Kirchman DL, Benner R, Whitledge TE (1996) Active cycling of organic carbon in the central Arctic Ocean. Nature 380:697-699

Wood AM, Van Valen V (1990) Paradox lost? On the release of energy-rich compounds by phytoplankton. Mar Microb Food Webs 4:175-206

Yager PL, Deming JW (1999) Pelagic microbial activity in an Arctic polynya: testing for temperature and substrate interactions using a kinetic approach. Limnol Oceanogr 44:1882-1893

Zlotnik I, Dubinsky Z (1989) The effect of light and temperature on DOC excretion by phytoplankton. Limnol Oceanogr 34:831-839

Submitted: June 25, 2002; Accepted: March 4, 2003

Proofs received from author(s): June 16, 2003 